NBER WORKING PAPER SERIES

\title{
STANDING ON THE SHOULDERS OF GIANTS: THE EFFECT OF PASSIVE INVESTORS ON ACTIVISM
}

\author{
Ian R. Appel \\ Todd A. Gormley \\ Donald B. Keim \\ Working Paper 22707 \\ http://www.nber.org/papers/w22707 \\ NATIONAL BUREAU OF ECONOMIC RESEARCH \\ 1050 Massachusetts Avenue \\ Cambridge, MA 02138 \\ September 2016
}

We thank Nicole Boysen, Alon Brav, Alex Edmans, Slava Fos, Nickolay Gantchev, Christopher Hennessey, Andrew Karoyli, Hyunseob Kim, Nadya Malenko, Pedro Matos, Jordan Nickerson, Min Pyo, Christopher Schwarz, Jules van Binsbergen, seminar and brown bag participants at Baylor University (Hankamer), Boston College (Carroll), Cornell University (Dyson), Lancaster University, London Business School, London School of Economics, Pennsylvania State University (Smeal), University of Pennsylvania (Wharton), Washington University in St. Louis (Olin), and participants at the Carnegie Mellon University Accounting Conference, European Finance Association Annual Meeting (Norway), FTSE 2016 World Investment Forum, FSU SunTrust Beach Conference, National Bureau of Economic Research Conference on Long-Term Asset Management, 2016 Norwegian Financial Research Conference, University of Kentucky Finance Conference, and Western Finance Association Annual Meeting (Park City) for helpful comments, Louis Yang for his research assistance, Alon Brav for sharing activism data, and the Rodney L. White Center for Financial Research for financial support. The views expressed herein are those of the authors and do not necessarily reflect the views of the National Bureau of Economic Research.

NBER working papers are circulated for discussion and comment purposes. They have not been peer-reviewed or been subject to the review by the NBER Board of Directors that accompanies official NBER publications.

(C) 2016 by Ian R. Appel, Todd A. Gormley, and Donald B. Keim. All rights reserved. Short sections of text, not to exceed two paragraphs, may be quoted without explicit permission provided that full credit, including $(\odot$ notice, is given to the source. 
Standing on the Shoulders of Giants: The Effect of Passive Investors on Activism Ian R. Appel, Todd A. Gormley, and Donald B. Keim

NBER Working Paper No. 22707

September 2016

JEL No. D22,G23,G30,G34

\section{ABSTRACT}

We analyze whether the growing importance of passive investors has influenced the campaigns, tactics, and successes of activists. We find activists are more likely to pursue changes to corporate control or influence (e.g., via board representation) and to forego more incremental changes to corporate policies when a larger share of the target company's stock is held by passively managed mutual funds. Furthermore, higher passive ownership is associated with increased use of proxy fights and a higher likelihood the activist obtains board representation or the sale of the targeted company. Overall, our findings suggest that the increasingly large ownership stakes of passive institutional investors mitigate free-rider problems associated with certain forms of intervention and ultimately increase the likelihood of success by activists.

Ian R. Appel

Boston College

Carroll School of Management

Department of Finance

140 Commonwealth Ave.

Chestnut Hill, MA 02467

USA

ian.appel@bc.edu

Todd A. Gormley

Olin Business School

Washington University in St. Louis

One Brookings Drive

Campus Box 1133

St. Louis, MO 63130

gormley@wustl.edu
Donald B. Keim

The Wharton School

Finance Department

University of Pennsylvania

3620 Locust Walk

Philadelphia, PA 19104-6367

keim@wharton.upenn.edu 
"This is the biggest shift in the battle for corporate control since private equity was invented in the 1980s... activists realize they can influence [the] concentrated shareholder base at many companies, and they're tapping into the desires of shareholders to see change take place."

- James Rossman, head of corporate preparedness at Lazard

The New York Times, March 18, 2014

\section{Introduction}

The willingness of investors to engage in activism has grown rapidly in recent years. Hundreds of activist campaigns are launched each year, and as noted by The Economist, the current "scale of their insurrection in America is unprecedented." Evidence also suggests the goals of activists have become more ambitious, and their success rate has improved. For example, activists increasingly wage proxy fights to obtain board representation, and more than $70 \%$ of these campaigns were successful in $2014 .^{2}$

At the same time, stock ownership by passive institutional investors has grown rapidly. Passively managed mutual funds, which seek to deliver the returns of a market index (e.g., S\&P 500) or particular investment style (e.g., large-cap value), have quadrupled their ownership share of the U.S. stock market over the last 15 years and now account for more than a third of all mutual fund assets (see Fig. 1). The institutions that offer these funds, like Vanguard and Blackrock, are now often the largest shareholders of U.S. companies, resulting in a significant increase in ownership concentration for many firms. In this paper, we examine whether these two concurrent trends are related. In particular, we analyze whether the increasingly large and concentrated ownership stakes of passive institutional investors influence the types of campaigns undertaken by activists, the tactics they employ, and their eventual outcomes.

One possibility is that the increased presence of passive institutions facilitates activism. Activist investors face a classic free-rider problem (Grossman and Hart, 1980) when considering intervention in a firm - the activist bears all costs associated with intervention, yet the benefits accrue across all shareholders. The large and concentrated ownership stakes of passive institutions might help overcome this problem by facilitating activist investors' ability to rally support for their demands (Brav et al., 2008; Bradley et al., 2010) and by decreasing the coordination costs of activism (e.g., during the proxy solicitation process). Furthermore, gaining the support of one or more passive institutions may lend

\footnotetext{
${ }^{1}$ See "Capitalism's unlikely heroes: why activist investors are good for the public company," The Economist, February 7, 2015. The Wall Street Journal also notes that activists have "cemented their position as a force in U.S. markets and boardrooms; see "Activists are on a roll, with more to come," The Wall Street Journal, January 1, 2015.

${ }^{2}$ For example, in an article titled, “Activist Investors Ramp Up, and Boardroom Rifts Ensue," The Wall Street Journal reports that the number of companies targeted by an activist seeking board representation has more than doubled in the last five years. And in a separate article, "CEOs Test: Contending With Activist Investors," The Wall Street Journal reports that activists seeking a board seat obtained at least a partial victory in $72 \%$ of such campaigns in 2014, up from a success rate of $57 \%$ in 2008 .
} 
credibility to a campaign and improve the likelihood of success, thereby increasing the expected benefits of activism. ${ }^{3}$ Finally, the inability of passive institutions to sell poorly performing stocks in their portfolios (due to their mandate to closely track underlying indexes) might make them willing and influential partners in an activist campaign, further increasing an activists' likelihood of success.

However, it is also possible that the growing clout of passive institutions might hamper activism. If, for example, passive investors "take little interest in how firms are run... [and] dislike becoming deeply involved in management" (The Economist, 2015), the increasing market share of such "lazy investors" could make it more difficult for activists to rally support for their demands. Some activists also argue that index fund managers have a potential conflict of interest because corporate pension plans are one of the largest investors in index funds, and a fear of losing these investors may deter them from supporting activists. ${ }^{4}$ Finally, as long-term investors, passive institutions might not share the same goals as activists if they have shorter-term objectives. For example, Larry Fink, the CEO of Blackrock, has expressed his unwillingness to support activist demands he sees as short-sighted and detrimental to long-term value, including demands for increased debt, dividends, and repurchases. ${ }^{5}$

Identifying the impact of passive investors on activists' choices and success rates poses an empirical challenge. The primary concern is that of omitted variables-because passive institutional portfolios are related to the composition of the indexes they track, passive ownership of a stock might be correlated with factors that directly affect activists' tactics and success rates. For example, poor past performance might cause both a stock's removal from a popular index, thus reducing passive ownership, and also increase the likelihood of activism. Thus, naïve correlations between passive institutional ownership and activism outcomes might not reflect a causal relation.

To overcome this challenge, we exploit variation in stock ownership by passive mutual funds that occurs around the cutoff point used to construct two widely-used market benchmarks, the Russell 1000 and Russell 2000 indexes. The Russell 1000 comprises the largest 1,000 U.S. stocks, in terms of market capitalization, and the Russell 2000 comprises the next largest 2,000 stocks. As shown in Appel, Gormley, and Keim (2016) (hereafter AGK), benchmarking by passive funds leads to a sharp difference in ownership

\footnotetext{
${ }^{3}$ For example, the activist hedge fund ValueAct was successful in obtaining a seat on Microsoft's board with less than $1 \%$ of stock because Microsoft recognized that other large institutional investors backed the fund's demand. And consistent with the potential decisive role these large investors can play, the activist hedge fund Jana Partners gauged potential support from large institutional investors before making demands of management at Agrium. See "New alliances in the battle for corporate control," The New York Times, March 18, 2014.

${ }^{4}$ For example, see hedge fund manager William A. Ackman's annual letter to the investors of Pershing Square Capital Management in December 2015.

${ }^{5}$ See "Blackrock's Larry Fink: Typical Activists Are Too Short-Term," The Wall Street Journal, January 16, 2014.
} 
by passive investors for stocks at the top of the Russell 2000 relative to stocks at the bottom of the Russell 1000 even though they are otherwise similar in terms of their overall market capitalization. During our sample period, the ownership by passively managed mutual funds is about $40 \%$ higher, on average, for stocks at the top of the Russell 2000 index relative to those at the bottom of the Russell 1000 index. Moreover, the ownership stakes of the largest passive investors - Vanguard, State Street, DFA, and BGI/Blackrock (the owners of iShares during our sample period) - are 30\% higher among stocks at the top of the Russell 2000; and each of these institutions' likelihood of owning more than 5\% of a firm's shares is higher by $60 \%$ on average for a stock at the top of the Russell 2000, while their likelihood of being a top 5 shareholder for such stocks is higher, on average, by $17 \%$. There is not, however, a corresponding difference in ownership around the Russell 1000/2000 cutoff by actively managed mutual funds.

Exploiting this variation in passive ownership around the Russell 1000/2000 cutoff in an instrumental variable (IV) estimation, we assess the effect of passive funds on the activism of other investors. Specifically, we follow the approach of AGK and instrument for ownership by passive funds with an indicator for assignment to the Russell 2000 in a given year. However, because our sample of activism events runs through 2014, we augment the specification of AGK to account for an important change in how Russell constructed the two indexes after 2006. Specifically, beginning in 2007, Russell implemented a "banding" policy in which stocks within a certain range of the cutoff would not switch indexes unless the change in their relative size ranking was sufficiently large. Our IV estimation relies on the assumption that, after conditioning on stocks' market capitalization and this banding policy, inclusion in the Russell 2000 index does not directly affect our outcomes of interest except through its impact on passive ownership. This assumption seems reasonable in our setting in that it is unclear why index inclusion would be directly related to activism outcomes after restricting the sample to stocks near the Russell $1000 / 2000$ cutoff and after controlling for the factors that determines index inclusion.

Using this estimation technique, we study the effect of passive investors on the types of campaigns undertaken by activists, the tactics they employ, and their eventual outcomes. Activist campaigns in the sample are classified into four categories based on their primary goal: (1) those seeking board representation; (2) those seeking to improve shareholder value by demanding policy changes (e.g., increased dividends); (3) other goals, which include campaigns related to shareholder proposals and exempt proxy solicitations (e.g., "just vote no" campaigns); and (4) 13D filings with no explicit activist intent. We also analyze the tactics of activist campaigns, including whether they initiate a proxy fight or launch a hostile offer. Finally, we consider the effects of passive investors on the eventual success of activism. For example, we examine if campaigns lead to board representation for the activist, increased 
dividends/payouts, changes in capital structure, governance reform, or a spinoff or acquisition of the firm.

Using our IV approach, we find that passive mutual funds have a significant impact on the nature of activism. While passive ownership is not associated with the overall prevalence of activist campaigns from 2008-2014, we show that the level of passive ownership is significantly related to the goals of activist campaigns. Specifically, among firms targeted by an activist, a one standard deviation increase in passive ownership is associated with about a 0.87 standard deviation increase in campaigns seeking board representation and a similar magnitude decrease in other types of campaigns, including those limited to shareholder proposals and exempt solicitations. The increase in campaigns seeking board representation is economically large, corresponding to a doubling in its overall frequency, and suggests activists set more ambitious goals when more of a company's stock is held by passive investors.

We also find that greater passive ownership is associated with the increased use of confrontational tactics by activists. While board representation can be gained through both friendly and confrontational approaches (Brav et al., 2008; Fos, 2015), we document a shift in the likelihood of activists employing hostile tactics in attempts to gain board seats when passive ownership is higher. Specifically, among firms targeted by an activist, a one standard deviation increase in passive ownership is associated with a 0.88 standard deviation increase in the likelihood of activists launching a proxy fight against incumbent directors. Furthermore, we find an increase in the total number of board seats sought when passive ownership is higher; a one standard deviation increase in passive ownership is associated with a 0.57 standard deviation increase in the number of seats sought by the activist.

Combined, our results suggest that the presence of passive institutions and their concentrated ownership stakes alter the strategic choices of activists and increase their willingness to engage in costlier forms of activism. Specifically, the costs associated with seeking board representation and initiating a proxy fight (e.g., hiring lawyers, bankers, etc.) can amount to millions of dollars (Gantchev, 2013), while pushing for a shareholder proposal or exempt solicitation is "easier, less costly and demand a lower level of commitment from dissidents" (Wilcox, 2005). Consistent with this shift towards more costly forms of activism, we also find that activists are more likely to seek reimbursement from the company for their campaign when passive ownership is higher.

Higher passive ownership also impacts activists' success rates. Activists are more successful in obtaining outcomes related to corporate governance or control, which are topics that receive considerable attention in the proxy voting guidelines of passive institutions (see AGK). When passive ownership is higher, we document a sizeable increase in the likelihood of a proxy settlement with management, which often results in the activist obtaining board representation. Specifically, a one standard deviation increase in passive ownership is associated with a 0.93 standard deviation increase in the likelihood of a proxy fight 
settlement. We also find a positive association between passive ownership and the likelihood of success for campaigns pertaining to corporate control, including the removal of takeover defenses and the sale of the firm to the activist or a third party. In contrast, we do not find evidence of effects related to policies passive investors sometimes associate with shorter-term goals, such as increased dividends and changes to the capital structure.

Finally, we find that the level of passive ownership is not related to the type of firms targeted by activists, another potential mechanism through which passive ownership might affect activism outcomes. Specifically, passive ownership is not associated with firm characteristics (e.g., past values of dividend yields, leverage, capital expenditures, return on assets, Tobin's Q, and stock returns) that have been identified in prior research to be related to the likelihood of being targeted by an activist.

Our findings are robust to various specification choices. For example, varying the functional form we use to control for firms' end-of-May market cap, which is the key factor determining stocks' index assignment each year, does not affect our findings, nor does modifying how we measure passive stock ownership. The findings are also robust to adding various controls, including (1) the liquidity of a firm's stock, (2) whether the firm recently switched indexes, and (3) the firms' float-adjusted market cap, which is a proprietary measure used by Russell to determine a stock's ranking within indexes. Our findings are also not sensitive to excluding activists that only file a 13D with no stated intent, or to only using end-ofMay market cap rankings to select our sample of stocks each year. In addition, we find no effect of passive ownership in placebo tests that assume differences in passive ownership at alternative market cap thresholds (i.e., instead of the Russell 1000/2000 cutoff), thus providing additional evidence that our findings are not driven by specification error. Finally, we find similar results during our sample period when we use the alternative activism data of Brav, Jiang, Partnoy, and Thomas (2008) and Brav, Jiang, and Kim (2010), which was recently extended through 2014. We find no evidence, however, of a relation between passive ownership and activism in the earlier years covered by this alternative database, which is consistent with anecdotal evidence that passive investors' openness to activism is a more recent development. ${ }^{6}$

In summary, our findings indicate that the increased presence of passive institutional investors has a significant impact on the types of campaigns, the tactics, and the success of activist investors. The findings are consistent with the concentrated ownership blocs of passive institutions both reducing the costs of certain activist tactics and increasing the expected benefits of activism. The results are also consistent with

\footnotetext{
${ }^{6}$ For example, Dimensional Fund Advisers "rarely engaged with activists before 2007 but formed a corporate governance group that year and started meeting with activist investors a few years ago." See "Activist investors find allies in mutual, pension funds," Reuters (April 9, 2013).
} 
the possibility that the presence of passive investors facilitates activists' ability to target firms with more intransigent managers that are less willing to enact change short of a proxy fight.

Overall, this paper contributes to the literature that studies the causes and effects of investor activism. A fundamental question in this literature is whether activists improve the long-term performance of firms, or if they are myopic in the sense of pushing for changes that boost short-term profits at the expense of long-term value. Previous papers document that governance deficiencies and disagreements over strategy are important triggers for shareholder activism (McCahery, Sautner, and Starks, 2014) and that activists tend to target smaller firms with higher operating performance and lower payouts and that their activities are associated with positive abnormal returns and changes to firm performance that are consistent with activists creating shareholder value. ${ }^{7}$ Activists have also been found to affect a wide range of other outcomes including innovation (Brav, Jiang, Ma, and Tian, 2014), corporate culture (Popadak, 2013), director labor markets (Fos and Tsoutsoura, 2014), labor productivity (Brav, Jiang, and Kim, 2015), mergers (Boyson, Gantchev, and Shivdasani, 2015), resistance by managers (Boyson and Pichler, 2016), and measures of adverse selection (Collin-Dufresne and Fos, 2015). While the effects of activism have been widely studied, relatively little is understood about how such investors choose their tactics and what factors contribute to their success. We contribute to this literature by showing that passive ownership has a significant impact on the tactics employed by activists and ultimately the outcome of these campaigns.

Our findings are also related to the recent strand of literature that explores coordinated actions by "wolf packs" consisting of multiple activists (e.g., Brav, Dasgupta, and Mathews, 2015; Coffee and Palia, 2015; Dimson, Karakas, and Li, 2015). Our findings contribute to this nascent literature by showing that activists' strategic choices may also be influenced by potential alliances with large passive institutional block holders, which represent an increasingly large component of US stock ownership.

Finally, we contribute to the growing literature on the effects of passive institutional investors. For example, AGK find that passive investors are able to use their significant voting power in an earlier sample period, 1998-2006, to exert influence over firms' governance choices (e.g., more independent directors, fewer takeover defenses, and more equal voting rights) and ultimately their performance. ${ }^{8}$ In contrast to this earlier work, this paper offers novel evidence that an increased presence of passive investors also affects

\footnotetext{
${ }^{7}$ See, for example, Bebchuk, Brav, and Jiang, 2015; Becht et al., 2009; Brav et al., 2008; Brav, Jiang, and Kim, 2009; Clifford, 2008; Greenwood and Schor, 2009; Klein and Zur, 2009. For comprehensive reviews of this literature see Brav, Jiang, and Kim, 2010; Denes, Karpoff, and McWilliams, 2015; Gillan and Starks, 2007.

${ }^{8}$ In a recent paper, Schmidt and Fahlenbrach (2016) use the endogenous switches from one index to the other as an alternative source of variation in passive ownership and find passive ownership is associated with weaker governance and reduced shareholder value. The tradeoffs of the different methodologies used in this identification setting are discussed in Appel, Gormley, and Keim (2015), which can be found at http://ssrn.com/abstract=2641548.
} 
the choices of activists, an entirely separate class of institutional investors that are widely thought to play an important role in governance. Thus, our evidence indicates that, while not engaging in traditional forms of activism themselves, passive investors have a meaningful impact on the activism of other investors, providing another distinct mechanism by which the recent growth of passive investors may be affecting the monitoring of managers and corporate performance.

\section{Sample, data sources, and descriptive statistics}

In this paper, we merge stock-level data on mutual fund ownership and Russell equity index membership with activist campaign data. We now briefly describe each data source and our sample.

\subsection{Mutual fund holdings and Russell 1000/2000 index membership}

We use the S12 mutual fund holdings data compiled by Thomson Reuters and available from Wharton Research Data Services (WRDS) to compute mutual fund holdings in a stock as a percent of its market capitalization. Since May 2004, all (open-end) mutual funds and exchange-traded funds (ETFs) holding stocks traded on U.S. exchanges are required to report those holdings every quarter to the SEC using Forms N-CSR and N-Q. ${ }^{9}$ Reported securities include all NYSE, Amex, Nasdaq, Toronto, and Montreal common stocks. We exclude observations where the total mutual fund holdings exceed a firm's market capitalization, and we calculate the total market cap of each stock using the CRSP monthly file as the sum of shares outstanding multiplied by price for each class of common stock associated with a firm.

To classify a mutual fund as either passively managed or actively managed, we use a method similar to that of Busse and Tong (2012) and Iliev and Lowry (2015). Specifically, we obtain fund names by merging the Thomson Reuters data with the CRSP Mutual Fund data using the MFLINKS table available on WRDS. We then flag a fund as passively managed if its fund name includes a string that identifies it as an index fund or if the CRSP Mutual Fund Database classifies the fund as an index fund. ${ }^{10}$ We classify all other mutual funds that can be matched to the CRSP mutual fund data as actively managed, and funds that cannot be matched are left unclassified. To generate variables for mutual fund ownership disaggregated into these three categories, we compute the percentage of each stock's market capitalization that is owned by passive, active, and unclassified mutual funds at the end of each quarter.

Our subsequent analysis is restricted to the sample of stocks in the Russell 1000 and 2000 indexes beginning with the 2007 reconstitution. We start the sample in 2007 to correspond with Russell's "banding"

\footnotetext{
${ }^{9}$ Hereafter, we collectively refer to the open-end and exchange-traded funds in our sample as mutual funds. Closedend funds, which are typically actively managed, are not in our sample.

${ }^{10}$ The strings we use to identify index funds are: Index, Idx, Indx, Ind_ (where _indicates a space), Russell, $S \& P, S$ and $P, S \& P$, SandP, SP, DOW, Dow, DJ, MSCI, Bloomberg, KBW, NASDAQ, NYSE, STOXX, FTSE, Wilshire, Morningstar, 100, 400, 500, 600, 900, 1000, 1500, 2000, and 5000 .
} 
policy (see next section for further details). Russell Investments provides index constituents as well as its proprietary measure for the float-adjusted market capitalization, which is used to determine the rank (i.e., portfolio weight) of each security within an index.

\subsection{Activism data}

We obtain data on corporate activist campaigns from SharkWatch (FactSet), which offers a comprehensive database of activism events. The source of the information in SharkWatch includes company/activist filings and press releases, news/trade publications, and company websites. The analysis in this paper is conducted at the event level.

We classify activist campaigns into four mutually exclusive categories based on their primary goal: (1) campaigns seeking board representation; (2) campaigns seeking to maximize shareholder value by advocating for specific policy changes; (3) all other campaign goals; and (4) 13D filings with no explicit activist intent. Campaigns seeking board representation capture cases where the activist attempts to replace either a subset of directors or to take control of the board. Campaigns seeking change in corporate policies include those where the activist seeks changes thought to improve shareholder value, including increased payouts, changes in the company's capital structure, or the sale of the company (exclusive of seeking board representation). Finally, "other goals" include campaigns where the activist only seeks an exempt solicitation or more modest goals like the adoption of a shareholder proposal. ${ }^{11}$

SharkWatch also includes 13D filings with no stated activist goals from 50 well-known activists (known as the SharkWatch50). A schedule 13D filing is required under Section 12 of the Securities Exchange Act when a shareholder's beneficial ownership exceeds 5\% and that shareholder plans to engage in activism. The purpose of the transaction (e.g., board representation) must also be provided in Item 4 of the 13D filing. Some institutions, however, will file a 13D but not declare specific intent to engage in activism. This is likely done to leave open the option of becoming more active in the future, and we classify these campaigns as "13D only." As discussed in Section 5, however, our main findings are robust to excluding activist campaigns associated with 13D filings with no stated goals.

We also use SharkWatch for data on tactics used by activists and the eventual outcome of each campaign. Specifically, we construct indicator variables for the most common tactics employed by activists, including proxy fights (which often involve activists seeking board representation), the drafting of shareholder proposals, or initiating a lawsuit. Finally, we construct indicators for the most common

11 An exempt solicitation under Rule 14a-2(b)(1) of the Securities Exchange Act of 1934 involves activists communicating with other shareholders but not soliciting proxies. Because exempt solicitations do not involve soliciting proxies, they are typically viewed as being a less costly form of activism (Wilcox, 2005). 
outcomes of an activist campaign: whether the activist campaign results in a proxy settlement; increased dividends/payouts; governance reform (not including activist representation on the board); or acquisition of the firm by either a third party or the activist.

\subsection{Sample and descriptive statistics}

For our main analysis, we restrict the sample to activist events occurring in the 500 bandwidth around the cutoff between the Russell 1000 and 2000 indexes, as determined using the end-of-June Russellassigned weights for stocks within each index. There are 466 such events for 310 unique firms, and for the firms targeted by multiple activist campaigns, 67 are in the same calendar year. We describe our bandwidth choice and the inherent tradeoffs we face in Section 3.

Table 1 reports summary statistics for our main sample. Total mutual fund ownership for the stocks in our sample, is $35.6 \%$. The largest component of mutual fund ownership is active investors (22.7\%), followed by passive (9.4\%), and unclassified investors (3.5\%). About $28 \%$ of all activist campaigns seek board representation as their primary goal, while seeking to maximize value by enacting policy changes represents $20 \%$ of campaigns. The remaining half of the campaigns are either classified as an "other campaign type" by SharkWatch $(38 \%)$ or are campaigns where the investor initiates a 13D filing indicating an intent to engage in activism but does not subsequently state its goals or tactics (14\%). Despite their highprofile nature, only about $19 \%$ of campaigns employ a proxy fight as one of their tactics. About $7 \%$ of campaigns (or about $36 \%$ of proxy fights) end in a proxy settlement, and activists only win proxy fights in $3.2 \%$ of campaigns (and $18 \%$ of proxy fights) during our sample.

\subsection{SharkWatch versus other activism datasets}

Another commonly used dataset in the activism literature is that of Brav, Jiang, Partnoy, and Thomas (2008) and Brav, Jiang, and Kim (2010). While we confirm our findings using this alternative dataset in later robustness tests, we use SharkWatch as our primary data source because it is not limited to hedge fund activism and covers considerably more campaigns during our sample period. Specifically, compared to the 466 campaigns in our sample, there are only 164 activist campaigns available during the same period in the extended data of Brav, Jiang, Partnoy, and Thomas (2008) and Brav, Jiang, and Kim (2010). A key difference between the databases is that Brav et al. limit their analysis to campaigns initiated by activist hedge funds, while SharkWatch also includes campaigns initiated by other types of institutional investors (e.g., pension funds), individuals, and other firms. Moreover, additional campaigns found in SharkWatch come from activist campaigns that do not include a 13D filing. Such filings are only required when an activist owns more than five percent of a company's equity. While Brav, et al. also make efforts 
to collect information on campaigns without a 13D filing, their data only includes 13 such campaigns during our sample period, whereas 185 of the 466 SharkWatch campaigns in our sample lack a 13D filing. ${ }^{12}$

\section{Empirical framework}

Identifying the impact of passive investors on the types of campaigns undertaken by activists, the tactics they employ, and their eventual outcomes poses an empirical challenge. Cross-sectional correlations between passive ownership and activism outcomes might not reflect a causal relation because ownership by passive investors could be correlated with factors—such as firms' stock liquidity or operating performance - that directly affect activism. Failure to control for such factors could introduce an omitted variable bias that confounds inferences. To overcome this challenge and to determine the importance of passive investors, we use stocks' assignment to the top of the Russell 2000 index as an exogenous shock to passive mutual fund ownership. We now describe our identification strategy.

\subsection{Russell index construction and passive institutional investors}

Passive funds attempt to match the performance of a market index by holding a basket of representative securities in the particular market index in proportion to their weights in the index. The most visible types of passive funds are index funds, which hold nearly all stocks in the market index rather than a representative sample.

Two market indexes widely used as benchmarks are the Russell 1000 and Russell 2000. During our sample period, the Russell 1000 comprises 1,000 U.S. stocks that mostly reflect the largest 1,000 companies in terms of market capitalization, while the Russell 2000 comprises the next largest 2,000 stocks that are not included in the Russell 1000. An example of an index fund that uses the Russell 1000 as a benchmark is the Vanguard Russell 1000 Index Fund (VRNIX), while the Vanguard Russell 2000 Index Fund (VRTIX) uses the Russell 2000 as a benchmark.

To account for changes in stocks' ranking by market cap, the Russell indexes are reconstituted each year on the last Friday of June. ${ }^{13}$ Russell Investments determines index assignment for the following twelve months using a combination of three factors-a stock's market capitalization as of the last trading day in

\footnotetext{
${ }^{12}$ In some cases, however, the Brav, et al. data source includes campaigns that are not found in SharkWatch. These campaigns, however, are often those where the activist filed a 13D with no stated goal and took no subsequent actions. SharkWatch only includes such campaigns from 50 well-known activists (known as the SharkWatch50), whereas the Brav, et al. data does not make this limitation.

${ }^{13}$ However, when the last Friday of June falls on the $29^{\text {th }}$ or $30^{\text {th }}$, the two indexes are reconstituted on the preceding Friday. During the following twelve months, stocks are only deleted from the indexes due to Chapter 7 bankruptcy filings, delistings, and corporate actions (takeovers), while IPOs are added quarterly to the indexes on the basis of the market capitalization breaks established during the most recent reconstitution. For more details regarding the reconstitution process and eligibility for inclusion in the Russell indexes, see Russell Investments (2013).
} 
May of that year, the stock's index assignment in the previous reconstitution year, and whether the stock's market cap falls within a certain range of the cutoff between $1,000^{\text {th }}$ and $1,001^{\text {st }}$ largest stock market caps. Specifically, a stock with an end-of-May market cap below (above) the market cap of the $1,000^{\text {th }}\left(1,001^{\text {st }}\right)$ largest market cap will be included in the Russell 2000 (Russell 1000) index unless that stock was included in the Russell 1000 (Russell 2000) last year and its market cap is not below (above) the market cap of the $1000^{\text {th }}\left(1001^{\text {st }}\right)$ largest market cap by more than $2.5 \%$ of the cumulative market cap of the Russell $3000 \mathrm{E}$ Index, which comprises the 4,000 largest stocks. This "banding” policy was implemented by Russell beginning in 2007 to minimize the number of stocks that switch indexes each year. Prior to 2007, the Russell 1000 simply included the 1,000 largest stocks at the end of the last trading day in May, while the Russell 2000 includes the next 2,000 largest stocks.

After index assignments are determined, each stock's weight in the index is then calculated using its end-of-June float-adjusted market cap. Unlike the market cap used to determine index membership, the float adjusted market cap only includes the value of shares that are available to the public. Shares held by another company or individual that exceed $10 \%$ of shares outstanding, by another member of a Russell index, by an employee stock ownership plan (ESOP), by a government, and those that are not listed on an exchange are not included when calculating a firm's float-adjusted market cap.

Because the Russell indexes are value-weighted, index assignment has a significant effect on index weights; the $950^{\text {th }}$ largest stock at the end of May is more likely to be included in the Russell 1000 and to be given a very small weight within its index, while the $1,050^{\text {th }}$ largest stock is more likely to be included in the Russell 2000 and to be given a much larger weight. For example, during our sample period, the average weight of the bottom 250 stocks in the Russell 1000 was $0.014 \%$, while the average weight of the top 250 stocks in the Russell 2000 was an order of magnitude larger at $0.145 \%$. The difference in index weights persists over a wide range around the cutoff. This is seen in Fig. 2, in which we plot the end-ofJune weights of the 500 smallest float-adjusted stocks in the Russell 1000 and the 500 largest float-adjusted stocks in the Russell 2000 for the year 2013.

These differences in index weights have a significant impact on the extent of a stock's ownership by passive investors. Because passive funds weight their holdings based on the weights in the underlying index in an attempt to minimize tracking error, it is more important that they match the weights of the stocks at the top of the index than of stocks at the bottom of the index. In other words, for each dollar invested in a passive fund benchmarked to the Russell 1000, very little of it will be invested in stocks at the bottom of that index, while for each dollar invested in a passive fund benchmarked to the Russell 2000, a large proportion of it will be invested in stocks at the top of the index. Because of the considerable amount of 
money passively tracking the two Russell indexes (Chang, Hong and Liskovich, 2015), the portfolio decisions of passive institutions lead to large ownership differences in stocks around the Russell 1000/2000 threshold.

The importance of index assignment for ownership by passive mutual funds is illustrated in Fig. 3, in which we rank stocks using their end-of-May CRSP market capitalization and plot the average share of firms in the Russell 2000 and average end-of-September ownership by passively managed funds. The sample in this figure contains the top 500 stocks of the Russell 2000 and bottom 500 stocks of the Russell 1000 for each year between 2007 and 2013, as determined using the end-of-June Russell-assigned weights within each index. By construction, the top panel of Fig. 3 shows a smooth relation between size and ranking, but as shown in the middle panel, there is a rather distinct relation between ranking and the probability of being assigned to the Russell 2000. The largest stocks are assigned to the to the Russell 1000; the smallest stocks are assigned to the Russell 2000; and in an intermediate range around the midpoint, there is a positive correlation between a stock's probability of being in the Russell 2000 and a stock's ranking. This upward slope for intermediate rankings reflects Russell's use of banding during our sample period, where stocks within a certain range of the cutoff are kept in their previous index. The bottom panel of Fig. 3 demonstrates that the ownership of passive funds across rankings closely tracks the share of stocks assigned to the Russell 2000. During our sample period, the total ownership stake of passive funds is, on average, 40\% higher for a stock among the top 500 stocks of the Russell 2000 relative to a stock among the bottom 500 stocks of the Russell 1000 ( $p$-value of difference $<0.001$ ).

The magnitude of the observed difference in passive ownership corresponds to the magnitude one would predict using estimates of the amount of passive assets tracking each of the two indexes. While the Russell 1000 is more than 10 times larger in total market cap than the Russell 2000 during our sample period, there is only about 2 to 3 times more dollars passively tracking the Russell 1000 relative to the Russell 2000 (see Table 1, Panel A of Chang, Hong, and Liskovich, 2015). ${ }^{\mathbf{1 4}}$ Using their estimates for 2010, $\$ 56.8$ billion in assets were passively tracking the Russell 2000, which accounts for about $4.93 \%$ of the index's total market cap of $\$ 1,115$ billion, while there was $\$ 137.1$ billion of assets passively tracking the Russell 1000, accounting for just $1.17 \%$ of the index's total market cap of $\$ 11,740$ billion. Based on these estimates, assignment to the Russell 2000 rather than to the Russell 1000 in that year would increase a stock's passive institutional ownership by about 3.8 percentage points, which is similar to the 3.4 percentage

\footnotetext{
${ }^{14}$ The disproportionate amount of money passively tracking the Russell 2000 occurs because the Russell 2000 is the most widely used market index for small cap stocks. The Russell 1000, which spans both large and midcap stocks, is less widely used as a benchmark because it faces more competition from other large cap and midcap market indexes, including the S\&P 500 (which is the most popular market index), the CRSP U.S. midcap index, and the S\&P 400 midcap index.
} 
point increase we detect in 2010 using our measure of passive ownership. In practice, the realized differences in passive ownership we detect will be slightly smaller around the cutoff than predicted by this simple back-of-the-envelope calculation because passive investments by some institutions, like pension funds, are not reported in the S12 mutual fund database.

The importance of index assignment for passive ownership is further highlighted by examining the total ownership stake of the largest passive institutions during our sample period-Vanguard, State Street, DFA, and BGI/Blackrock (the owners of iShares during our sample). For this, we use the Thomson Reuters Institutional Holdings (13F) Database, which reports the total holdings, both passive and active, of each institution. On average, the ownership stake of each of these four institutions is $30 \%$ higher for the 500 firms at the top of the Russell 2000 relative to the bottom 500 firms of the Russell 1000, while the likelihood of each institution owning more than 5\% of a firm's shares is $60 \%$ higher and the likelihood of each institution being a top five shareholder is $17 \%$ higher.

We find no evidence that index assignment is related to an increase in ownership by actively managed funds and unclassified funds. We formally test and demonstrate this in Section 3.3.

\subsection{Identification strategy and empirical specification}

We use the construction of the Russell 1000 and 2000 indexes as a source of exogenous variation in ownership by passive mutual funds. Stocks at the top of the Russell 2000 exhibit greater ownership by passive investors because of their larger weights in the index, while stocks at the bottom of the Russell 1000 do not. Because index assignment is determined by an arbitrary rule surrounding the market capitalization of the $1,000^{\text {th }}$ largest firm and firm's past index assignment, this variation in ownership is plausibly exogenous after conditioning on the three factors that determine a firm's index assignment-market capitalization, past index assignment, and whether the firm's market capitalization falls within a certain range of the $1,000^{\text {th }}$ largest firm.

Following AGK, we use an instrumental variable strategy to identify the effect of ownership by passive mutual funds on activism tactics and outcomes. Specifically, we use inclusion in the Russell 2000 as an instrument for ownership by passive funds and include a robust set of controls for stocks' end-of-May market capitalization in our estimation. ${ }^{15}$

\footnotetext{
${ }^{15}$ Other recent papers use the Russell 1000/2000 cutoff as a source of variation in institutional investors' portfolio weights (Fich, Harford, and Tran, 2015) and total institutional ownership, as measured in the 13F filings, (e.g., see Bird and Karolyi, 2016; Boone and White, 2014; Crane, Michenaud, and Weston, 2016; Mullins, 2014, among others). AGK show that the observed increase in institutional ownership is driven by the holdings of passive institutional investors, thus allowing one to use index assignment as an instrument for passive ownership. Using an alternative estimation, Schmidt and Fahlenbrach (2016) also use index assignments as an IV for passive ownership. The tradeoffs of the different methodologies used in this identification setting are discussed in Appel, Gormley, and Keim (2015), which can be found at http://ssrn.com/abstract=2641548.
} 
Unlike AGK, however, our sample period occurs after Russell's switch to using additional thresholds and past index assignments to determine a stock's yearly index assignment. We therefore augment their IV specification to include three additional controls for each firm $i$ and reconstitution year $t$ (i.e., from end-of-June year $t$ to end-of-June year $t+1$ ): (1) an indicator for having an end-of-May market capitalization that ensures firm $i$ will not switch indexes in reconstitution year $t$ because the distance between its market cap and the Russell 1000/2000 cutoff is less than 2.5\% of the Russell 3000E Index

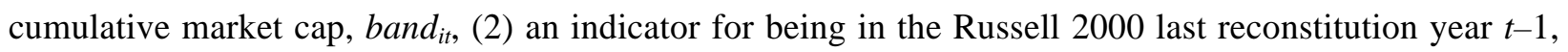
$R 2000_{i t-1}$, and (3) the interaction of these two indicators. These three additional controls capture the additional criteria used by Russell beginning in 2007 when determining each firm's index assignment at the annual end-of-June reconstitution for year $t .^{16}$

Specifically, we estimate the following activism event-level regression:

$$
\begin{aligned}
Y_{\text {eit }+1}= & \alpha+\beta{\text { Passive } \%_{i t}}+\sum_{n=1}^{N} \theta_{n}\left(\text { Ln }_{\text {Mktcap }}\right)^{n}+\gamma \operatorname{Ln}\left(\text { Float }_{i t}\right) \\
& +\mu_{1} \text { band }_{i t}+\mu_{2} R 2000_{i t-1}+\mu_{3}\left(\text { band }_{i t} \times R 2000_{i t-1}\right)+\delta_{t}+\varepsilon_{\text {eit }}
\end{aligned}
$$

where $Y_{e i t+1}$ is the outcome of interest for activism event $e$ targeting firm $i$ in year $t+1$ scaled by its sample standard deviation; Passive $\%_{i t}$ is the percent of a firm's shares held by passively managed mutual funds at the end of the end of September in year $t$ (i.e., in the first quarter after reconstitution in year $t$ ) scaled by its sample standard deviation; Mktcap $i t$ is the end-of-May CRSP market capitalization of stock $i$ in year $t$; Float $_{i t}$ is the float-adjusted market capitalization calculated by Russell when setting the portfolio weights during the end-of-June reconstitution. We scale both $Y_{\text {eit }+1}$ and Passive $\%_{i t}$ by their sample standard deviations so that the point estimate of $\beta$ can be interpreted as the standard deviation difference in $Y_{\text {eit }+1}$ for a one standard deviation increase in Passive $\%_{\text {it }}$. We control for float-adjusted market capitalization because Russell uses it to compute portfolio weights and could be related to a firm's stock liquidity, which might affect activism. We also include year fixed effects, $\delta_{t}$, to ensure that our estimates are identified using within-year variation in ownership and are not driven by the aggregate upward trend in ownership by passive investors (see Fig. 1). Finally, we cluster the standard errors, $\varepsilon_{e i t}$, at the firm level. ${ }^{17}$

To account for the possibility that ownership by passive funds, as measured using Passive\%, might

\footnotetext{
${ }^{16}$ These additional controls are necessary to account for how banding affects the configuration of firms around the cutoff between the Russell 1000 and 2000 indexes. In the post-banding period, stocks with better past stock returns will tend to remain in the Russell 2000 while stocks with worse past stock returns will tend to be kept in the Russell 1000. The importance of including these additional controls in the post-banding period tradeoffs is discussed in Appel, Gormley, and Keim (2015), which can be found at http://ssrn.com/abstract=2641548.

${ }^{17}$ We do not include firm fixed effects in our estimation because only a small fraction of our sample firms switch indexes at some point during the sample and because most firms do not experience multiple activism events.
} 
be correlated with the error term, $\varepsilon_{e i t}$, because of the omitted variable issues discussed above, we instrument for ownership by passive funds using index assignment. Specifically, we instrument Passive\% in the above estimation using $R 2000_{i t}$, which is an indicator equal to one if stock $i$ is part of the Russell 2000 index in reconstitution year $t$. As shown in Fig. 3, being assigned to the Russell 2000 is associated with a significant increase in ownership by passive funds for stocks at the top of Russell 2000 relative to stocks at the bottom of the Russell 1000.

Our IV estimation relies on the assumption that, after conditioning on the criteria used to determine a stock's index assignment, inclusion in the Russell 2000 index is associated with an increase in Passive\% (relevance condition) but does not directly affect our outcomes of interest except through its impact on ownership by passive investors (exclusion restriction). We verify the relevance condition below in our first stage estimations, and the exclusion restriction seems reasonable in that it is unclear why index inclusion would be directly related to our outcomes of interest after robustly controlling for the factors that determine index inclusion, including a firms' end-of-May market capitalization, as calculated by Russell. To control for firms' market capitalization, we restrict our sample to activism events that occur for the 500 stocks at the bottom of the Russell 1000 and top 500 stocks of the Russell 2000, and we include a robust set of controls for firms' log market capitalization, Ln(Mktcap), as measured using CRSP data, by varying the polynomial order $N$ we use to control for end-of-May market capitalization. ${ }^{\mathbf{1 8}}$

The use of $R 2000_{i t}$ as an instrument allows us to isolate an exogenous source of variation in passive ownership. While non-index funds that passively seek to deliver the performance of a benchmark portfolio have discretion over which stocks within the benchmark to hold, the instrumental variable never uses such endogenous variation in passive ownership; the IV estimation only uses variation in ownership that is driven by a stock's index assignment and the reshuffling of holdings by passively managed mutual funds seeking to minimize their tracking error. We do not use the actual portfolio weight or ranks of stocks as our instrument because this would introduce a potentially serious endogeneity concern. ${ }^{19}$

\footnotetext{
${ }^{18}$ Our estimation can be viewed as one that makes use of a threshold event in a non-RD estimation, as discussed in Bakke and Whited (2012), and we face a classic tradeoff of bias versus noise in choosing the bandwidth of observations to include around the threshold. While a smaller bandwidth (i.e., fewer than 500 stocks) around the threshold would reduce potential estimation bias due to a difference in average market capitalization across the two Russell indexes, it comes at the expense of fewer observations and greater estimation noise. Likewise, a wider bandwidth (i.e., greater than 500 stocks) might reduce estimation noise, but increases the risk of bias from inadequate controls for firm market capitalization. Using a wider bandwidth also poses a problem in our setting in that it weakens the power of our instrumental variable by including many stocks in the S\&P 500 index, which also affects a stock's extent of passive ownership in ways that would not be captured by our IV estimation. In subsequent robustness checks, we find that our main results are largely unchanged for wider bandwidths and qualitatively similar when using smaller bandwidths.

${ }^{19}$ See Appel, Gormley, and Keim (2015, 2016) for more details. Chang, Hong, and Liskovich (2015) and Mullins (2014) also discuss this issue of why the actual weights or rankings should not be used as instruments or as part of a regression discontinuity estimation in the Russell 1000/2000 setting.
} 


\subsection{First stage estimation}

In this section, we report estimates of our first-stage regression of passive mutual fund holdings on membership in the Russell 2000 index plus additional controls. Specifically, we estimate

$$
\begin{aligned}
{\text { Passive } \%_{i t}=} & \eta+\lambda \text { R2000 }_{i t}+\sum_{n=1}^{N} \chi_{n}\left(\operatorname{Ln}_{\left(\text {Mktcap }_{i t}\right)^{n}+\sigma \operatorname{Ln}\left(\text { Float }_{i t}\right)}\right. \\
& +\phi_{1} \text { band }_{i t}+\phi_{2} R 2000_{i t-1}+\phi_{3}\left(\text { band }_{i t} \times R 2000_{i t-1}\right)+\delta_{t}+u_{\text {eit }}
\end{aligned}
$$

where $R 200 O_{i t}$ is a dummy variable equal to one if stock $i$ is in the Russell 2000 for reconstitution year $t$, and the other variables are as defined for equation (1). In our initial tests, we also analyze other outcome measures, including the percentage of shares outstanding owned by all mutual funds; the percentage of shares outstanding owned by actively managed funds; and the percentage of shares outstanding owned by unclassified mutual funds. The model is estimated using all activism events from 2008 through 2014 that targeted firms within a bandwidth of 500 stocks around the Russell 1000/2000 threshold and includes a second-order polynomial for $\operatorname{Ln}($ Mktcap).

The results, reported in Table 2, confirm that a targeted firm's passive ownership structure is related to index assignment. In order for the point estimates in Table 2 to align with the observed differences in ownership shown in Fig. 3, we do not scale the ownership variables by their sample standard deviations in these initial estimates. The first column shows that aggregate mutual fund ownership is higher for activist targets that are at the top of the Russell 2000, but the estimate is not statistically significant. Breaking mutual fund ownership into its different investment styles, however, we see that index assignment is associated with the composition of a target's ownership. The level of passive ownership for targeted firms that are included in the Russell 2000 is about 4.3 percentage points greater than the level of passive ownership observed for targeted firms that are in the Russell 1000. The estimated coefficient is positive and significant at the $1 \%$ level (column 2). There is no evidence that index assignment is related to ownership of either actively managed mutual funds (column 3) or unclassified funds (column 4).

In Table 3 we demonstrate that the estimated relation between passive ownership and Russell 2000 membership is robust to using a higher- and lower-order polynomials, and to better quantify the economic magnitude of the observed difference in ownership, we scale Passive\% by its sample standard deviation. Using activism events that target firms within a bandwidth of 500 firms and varying the polynomial order of controls for market cap, we find an increase in ownership by passive funds of about one standard deviation (Table 3, columns 1-3). In all cases, the increase is statistically significant at the $1 \%$ level. $^{\mathbf{2 0}}$

\footnotetext{
${ }^{20}$ Because our IV model is just-identified, the IV estimation is median-unbiased and weak instruments are unlikely to be a concern in our setting, especially given the strong first stage estimates (Angrist and Pischke, 2009). Additionally, the Kleibergen-Paap F stat on the excluded instrument exceeds 10, providing further confidence that a weak instrument is unlikely to be a concern (Stock, Wright, and Yogo, 2002; Angrist and Pischke, 2009).
} 
The lack of a difference in ownership of actively managed and unclassified mutual funds is also robust to varying the polynomial order of controls for Mktcap. This can be seen in Appendix Table 2. The point estimates for both active ownership and unclassified ownership are economically small and not statistically significant in any of the specifications. Overall, our first stage estimates confirm that index assignment corresponds with a shift in passive ownership.

\subsection{Why index assignment might matter}

A question that might arise is why index assignment matters at all for passive ownership of a stock and its potential impact on activism. If higher passive ownership allows activists to exert additional influence (as our results below suggest), why would passive investors not also increase their ownership stake among other stocks so as to facilitate activism among those companies as well? In other words, what friction would prevent passive institutions or activists from accumulating more shares, and hence, undoing the potential importance of index assignment for passive institutional ownership?

There are two likely explanations for why index assignment might matter for passive ownership and activism. First, passive institutions are simply more focused on minimizing expenses and tracking error than on facilitating activism. While increasing an ownership stake for one stock at the bottom of the Russell 1000 might not significantly affect a fund's tracking error relative to the benchmark, a similar increase for a number of other stocks likely would. Second, index assignment can create a coordinated increase in ownership by institutions that might otherwise be hard to replicate. Specifically, achieving the same total increase in ownership may not be feasible for a single institution, and coordinating a combined ownership increase among multiple institutions might either be too costly or impose additional regulatory disclosure requirements these institutions typically wish to avoid.

Overall, our finding that index assignment corresponds with a shift in passive ownership suggests that institutions managing passive funds are not active in the traditional sense of trying to accumulate or exit positions because such actions are inconsistent with their passive mandate. It also suggests that the additional combined ownership stake of passive investors, and the influence it yields, is not something activists can easily replicate on their own.

\section{How passive investors affect activism by other investors}

Does the increased presence of passive investors have an effect on the types of campaigns undertaken by activists, the tactics they employ, and their eventual outcomes? In this section, we investigate these questions using the identification strategy and instrumental variable estimation described in Section 3. We also analyze the impact of passive investors on the frequency of activism. 


\subsection{Passive ownership and the likelihood of activism}

We first examine whether passive ownership affects the likelihood of a firm being targeted by an activist. Theoretically, even if the presence of passive investors facilitates activism by lowering its cost or by increasing the expected payoff of intervention, the effect of passive ownership on the frequency of activism is ambiguous. By facilitating activism, the presence of passive investors might increase its frequency. On the other hand, if managers internalize this possibility and act to preempt activist campaigns (e.g., through a reform of governance practices) because such campaigns are personally costly for the manager (Fos and Tsoutsoura, 2014), the presence of passive investors might lower the frequency of activism. We might also observe a decline in the likelihood of activism if passive investors take the initiative themselves (e.g., voting for more independent directors) to improve firm-level governance and performance for some firms (as found in AGK) thus (at least partially) negating the need for activism by others.

We use the IV estimation to analyze whether passive investors affect the likelihood of an activist campaign. The results of this analysis are reported in Table 4. The dependent variable is an indicator for activism constructed using the SharkWatch database. The sample consists of all observations in the 500 bandwidth around the Russell 1000/2000 cutoff during our sample period.

We find that the estimated effect of passive ownership on the likelihood of activism is negative, but statistically indistinguishable from zero. These estimates differ slightly from those found in AGK who document a similarly small, but statistically significant, negative association between passive ownership and the likelihood of hedge fund activism during the earlier 1998-2006 period. They attribute the negative association to passive investors reducing the need for activism. While negligible, the attenuation of this negative association between passive ownership and the likelihood of activism in the 2008-2014 period could be consistent with anecdotal evidence that passive investors have grown more willing to support activist campaigns in recent years as part of their broader agenda to improve corporate governance. The lack of a statistically significant effect during our later sample period does not depend on how we measure the occurrence of an activism event; omitting "13D only" activism events does not qualitatively change the findings, nor does using activism events, as defined in the data constructed by Brav et al.

\subsection{Type of activist campaigns}

We now turn attention to whether passive ownership affects the types of campaigns initiated by activists. The presence of passive investors might affect the composition of activist campaigns, even absent a change in the frequency, by differentially affecting the expected costs or benefits of different types of campaigns. For example, if governance- or board-related issues, such as board independence, are more important to passive investors, then activists might be more likely seek board representation as part of their 
campaign. And, if passive investors tend to view policy changes, like increased dividends or debt, as either short-sighted or beyond their scope of expertise, then activists may be less likely to initiate campaigns where such specific policy changes are the primary goal because of less expected support from passive investors. To analyze this possible shift in the composition of campaigns, we now (and for the remainder of the paper) restrict the sample to those firms in the 500 bandwidth that experience an activist event as defined by SharkWatch from 2008 through 2014.

Activists pursue a variety of different goals through their campaigns. While some campaigns seek to alter the fundamental aspects of governance such as control of the corporation, others seek more modest goals such pressuring management to increase payouts to shareholders or to provide additional disclosures. The two most common goals are (1) board representation and (2) policy changes thought to enhance value (e.g., changes to financial policies). The remainder of the campaigns seek a wide-range of different outcomes, including the adoption of shareholder proposals, sending exempt solicitations to other shareholders, and those related to idiosyncratic firm events (e.g., blocking a merger).

To analyze the effect of passive ownership on campaign types, we classify each activism event in the sample into one of three groups based on its primary goal, as defined by SharkWatch: board representation $(27.9 \%$ of sample), value-enhancing policy changes (19.5\% of the sample), and other (38.2\%). The remaining $14.4 \%$ of events are those where a well-known activist filed a 13D form but never explicitly stated activist intent; we define these as "13D only" campaigns. Table 5 reports the effects of passive ownership on each of the four groups of activist campaigns classified above.

We find that higher passive ownership leads to an increase in campaigns seeking board representation. Specifically, among firms targeted by an activist during our sample period, a one standard deviation increase in passive ownership is associated with a 0.73 standard deviation increase in the likelihood that the activist campaigns seek board representation ( $p$-value $<0.05$, Table 5, column 1 ). The increase is robust to including higher-order polynomial controls for firm's end-of-May market cap. We observe about a $0.87-0.88$ standard deviation increase in campaigns related to board representation when including a second- or third-order polynomial control for market cap, and both estimates are statistically significant at the $1 \%$ level (Table 5, columns 2-3).

Given the lack of a relation between the likelihood of activism and passive ownership reported in Table 4, the increased likelihood of campaigns seeking board representation associated with higher passive ownership must be offset by a drop in likelihood of other types of campaigns. We report results for "policy change," "other," and "13D only" campaigns in Columns 4-6 of Table 5. For brevity, we only report estimates that include a second-order polynomial control for market cap. The increased likelihood of 
campaigns seeking board representation appears to largely come at the expense of campaigns under the "other" categorization. Specifically, a one standard deviation increase in passive ownership is associated with a 0.64 standard deviation decrease in the likelihood of campaigns classified as other; the estimate, however, is not statistically significant at conventional levels (Table 6 , column $6, p=10.4 \%$ ). We also find a negative point estimate for the likelihood of a campaign seeking policy changes (column 4), but the estimate is not statistically significant. The association between passive ownership and the likelihood of a “13D only" filing is positive, but economically small and not statistically significant (column 5).

Overall, the results indicate that passive ownership leads to a meaningful shift in the types of campaigns pursued by activists. Specifically, higher passive ownership is associated with activists being more inclined to initiate campaigns seeking to alter the balance of corporate control away from incumbent directors. While activists are not necessarily seeking full control of the board in such campaigns, an attempt to get "a chair at the metaphorical table where corporate strategy is set" represents an ambitious intervention on the part of the activist that holds the potential to affect firms along virtually any dimension (Kahan and Rock, 2007). The increase in campaigns seeking board representation appears to be offset by a decrease in campaigns seeking incremental changes to firm policies through the use of shareholder non-binding resolutions, exempt solicitations, and other means.

\subsection{Board representation and proxy fights}

Why is passive ownership associated with activist investors pursuing board representation? One possible explanation, as discussed above, is that passive investors tend to focus on governance- and boardrelated issues. Knowing this, activists might tailor their campaigns to attract the support of the large passive institutions. Another, but not mutually exclusive, possibility is that the presence of passive investors might lower the cost of a common tactic used by activists to win board seats: proxy fights. Passive investors' concentrated ownership stakes might facilitate proxy battles by activists by reducing their coordination costs and ultimately increasing the chances of a favorable outcome. We analyze this possibility by examining whether passive investors influence the likelihood of activists engaging in a proxy fight with management and whether activists are more likely to obtain a successful outcome.

Proxy fights differ from many other activist tactics due to their considerable cost. These costs can be both direct (e.g., proxy solicitation services, legal fees, etc.) and indirect (e.g., effort) in nature. For example, one obviously important aspect of a proxy fight is convincing other shareholders to vote for the dissident directors. However, communication with other shareholders is complicated by the fact that many hold shares in "street name" and cannot easily be identified. Thus, activists must hire proxy solicitation services. The costs associated with this are often considerable. For example, one study estimates the proxy 
solicitor fees alone cost activists $\$ 150,000$ on average when the activist issues a preliminary or definitive proxy statement (Activist Insights, 2014). Furthermore, activists often meet with other shareholders to convince them to vote for the dissident slate; Bebchuk (2007) notes that Red Zone LLC spent $\$ 950,000$ for travel alone in its proxy fight against Six Flags. Overall, Gantchev (2013) estimates the total average cost of a campaign ending in a proxy fight to be over $\$ 10$ million.

Other types of activism, like supporting a particular shareholder proposal or seeking an exempt solicitation, are usually less costly. For example, the primary direct cost for exempt solicitations is to "EDGARize" (i.e., format in accordance with SEC guidelines) the filing, which costs about $\$ 100{ }^{21}$ An exempt solicitation features the dissident writing a letter to other shareholders, so indirect costs are likely minimal as well. Similarly, there is no cost to submit shareholder proposals for inclusion on a company's proxy statement provided that certain ownership and procedural requirements are satisfied (Briggs, 2007).

Similar to the overall likelihood of activism, however, the theoretical effect of passive ownership on the likelihood of a proxy fight is ambiguous. Passive investors, and their large, concentrated ownership stakes, might reduce the total coordination costs of a proxy contest for an activist. Passive investors might also be more motivated than other investors to be engaged owners and to support an activist during a proxy fight since their desire to minimize tracking error makes them less able than actively managed funds to divest their holdings in poorly performing stocks. In both scenarios, we might observe an increase in the likelihood of a proxy contests when passive ownership is higher. But, if managers internalize the lower costs of proxy fights or the potential willingness of large passive institutions to support an activists' campaign, then they might be more likely to concede to an activist's demands earlier, thus eliminating the need for a proxy fight. In this latter case, higher passive ownership might instead be associated with fewer proxy fights.

A shift in the composition of targets might also affect the likelihood of proxy fights. The presence of passive investors (and their potential to make activism less costly or more successful) might cause more responsive managers to make changes to preempt an activist campaign. If true, this might cause activists to shift their attention to intransigent managers that are less willing to back down short of an actual proxy fight. In this scenario, we might again observe a shift towards more proxy fights when passive ownership is higher because the lower costs and increased expected benefits of a proxy fight allow activists to target firms and managers they might not be willing to target otherwise.

\footnotetext{
${ }^{21}$ See "Use of Exempt Solicitations Up Dramatically in 2012: Chesapeake (CHK) Latest Example" available at http://www.corpgov.net/2012/05/use-of-exempt-solicitations-up-dramatically-in-2012-chesapeake-chk-latestexample/
} 
Consistent with the idea that passive investors lower the costs and increase the expected benefits of launching a proxy fight, we find that higher passive ownership is associated with an increase in campaigns involving a proxy fight. These results are reported in Table 6. Specifically, among firms targeted by an activist, a one standard deviation increase in passive ownership is associated with a $0.85-0.88$ standard deviation increase in the likelihood of a proxy fight, and the point estimates are statistically significant at the 5\% level (columns 1-3). Activists also appear to be more ambitious in the number of board seats they seek when passive ownership is higher. A one standard deviation increase in passive ownership is associated with about a 0.57 standard deviation increase in the number of board seats sought by the activist (columns 4-6; statistically significant at the 5\% level).

Consistent with the presence of passive investors increasing the expected benefits of launching a proxy battle, we also find that greater passive ownership is associated with more favorable proxy fight outcomes for the activist. These results are reported in Table 7. The dependent variable in columns 1-3 is an indicator for management settling a proxy fight with the activist, which is typically associated with some board representation and construed as a positive outcome for the activist. A one standard deviation increase in passive ownership is associated with approximately a 0.76-0.93 standard deviation increase in the likelihood that an activist campaign results in a proxy settlement and the estimates are statistically significant at the 5\% level. These findings suggest that the ex-ante probability that an activist will win a proxy fight is higher when backed by passive investors, and therefore, managers are more likely to offer a settlement to save face and avoid losing the official vote. As additional evidence that managers internalize the risk of losing a proxy fight, we find less evidence that passive ownership is associated with differences in the rates at which activists or managers win proxy fights that go to a vote (columns 4 and 5). The increase in settlements but lack of an increase in vote outcomes that favor the activist suggests managers internalize their chance of success when deciding whether to offer activists a settlement.

Overall, the findings suggest passive investors play a key role in proxy battles. Specifically, passive ownership is associated with an increased likelihood of activists initiating a proxy fight, and an increased frequency of managers capitulating to activists' demands and offering a settlement during the proxy fight. Both results are consistent with passive investors lowering the costs associated with this particular form of intervention and/or increasing its expected payoff.

\subsection{Other activism outcomes}

In this section, we test whether passive ownership is associated with activists' likelihood of success in dimensions besides proxy fights and board representation. To do this, we collect information on other 
common activist outcomes from SharkWatch's campaign summaries, and create indicator variables to flag campaigns where the activist was successful in obtaining specific policy outcomes. The outcomes relate to both corporate control and governance (acquisitions and takeover defenses) and other corporate policies (increased payouts, capital structure changes, and spinoffs). For brevity, we continue to restrict our analysis to estimations that include a second-order polynomial control for $\operatorname{Ln}$ (market cap).

Our results, reported in Table 8, indicate that passive investors have a significant effect on the likelihood of activists achieving outcomes related to changes in corporate control. For example, passive ownership is associated with an increased likelihood that activists successfully push for an acquisition of the target. Among firms targeted by activists, a one standard deviation increase in passive ownership is associated with about a 0.86 standard deviation increase in the likelihood the activist successfully seeks and obtains an acquisition by a third party (column 1) and a 0.53 standard deviation increase in the likelihood the activist seeks and acquires the target firm itself (column 2). Both estimates are statistically significant at the $10 \%$ level. Given the potentially large value implications of these outcomes, increased activist success might be the result of a credible threat of a proxy fight should the activist face resistance from managers. Furthermore, the findings are consistent with passive investors being inclined to support acquisitions where shareholders are being offered a premium. Greater passive ownership, however, is also associated with a decline in the likelihood an activist is able to successfully block a merger or agitate for a higher price in a proposed merger (column 3). One potential explanation for this latter finding is that passive investors often hold significant ownership stakes in both the acquirer and the target, thus mitigating their incentive to support a higher price.

We also find that greater passive ownership is associated with increased success by activists in removing takeover defenses. Reform of governance practices, including the removal of takeover defenses, is a common goal of activists. We find that a one standard deviation increase in passive ownership is associated with a 0.36 standard deviation increase in the likelihood of the firm removing a takeover defense (Table 8, column 4). This finding is consistent with recent evidence that passive investors tend to oppose takeover defenses (Appel, Gormley, and Keim, 2016).

An increased presence of passive investors, however, does not appear to have an effect on activists' ability to instigate changes to other corporate policies that are at the sole discretion of managers and boards. Specifically, passive ownership is not related to success in obtaining an increase in payouts (Table 8, column 5), changing the capital structure (column 6), or facilitating a spinoff (column 7), three common goals of activist campaigns. While it might be the case that managers and boards are inclined to make such changes if refusal to do so could result in a proxy fight, it may also be the case that a proxy fight in response 
to refusal is viewed as a non-credible threat. This would be the case, for instance, if the proportional increase in value resulting from a change in firm policies does not outweigh the costs of a proxy fight for the activist. The non-findings are also consistent with passive investors being less inclined to support such changes because they view them as either better left to the discretion of managers and boards (Appel, Gormley, and Keim, 2016) or short-sighted (as argued recently by Larry Fink, CEO of Blackrock).

\subsection{Other types of activist tactics}

In practice, activists can employ a combination of tactics besides nominating a slate of directors and initiating a proxy fight. The most common activist tactic is to write a letter to the board and other shareholders. Other tactics can include initiating a lawsuit, obtaining a vote on a precatory shareholder proposal, pushing for a vote on a binding proposal, and seeking reimbursement for expenses occurred. We report findings pertaining to these other activist tactics in Table 9.

Passive ownership has less effect on the other tactics pursued by activists. While there is suggestive evidence that passive ownership is associated with an increase in the likelihood an activist initiates a lawsuit, which is generally considered a more hostile tactic, the point estimate is not statistically significant at conventional levels (Table 9, column 1). Likewise, we find little evidence that passive ownership is associated with the frequency of a letter to shareholders or the likelihood of using a precatory shareholder proposal, both of which are relatively lower-cost tactics. In both cases, the point estimates are negative but not statistically significant (columns 2-3). We also find little association between passive ownership and activists pushing a binding proposal (column 4).

Passive ownership, however, is associated with an increase in activists seeking reimbursement from the firm. Such requests are often made in expensive proxy fights, and consistent with the earlier observed increase in proxy fights, we find that a one standard deviation increase in passive ownership is associated with about a 0.62 standard deviation increase in the likelihood the activist seeks reimbursement. This finding provides additional evidence that activists undertake more expensive campaigns in the presence of higher passive ownership.

\subsection{Activism targets and ownership stakes}

Finally, we examine whether passive ownership is associated with a change in the types of firms targeted by activists or the size of the ownership stakes taken by activists. If passive ownership affects the choice of targets by activists, this could be another potential mechanism by which their presence affects the strategic choices of activists. For example, the documented positive association between passive ownership and proxy fights could reflect activists being more willing and able to target firms with intransigent managers and boards. The presence of passive investors might also influence the size of the ownership 
stake taken by activists. For example, activists might be able to take smaller positions in the targeted firm if they can expect the support of large passive institutions. Alternatively, activists might take larger positions if this expected support increases the likelihood of success for their campaign.

We find no evidence, however, that passive mutual fund ownership is associated with the characteristics of firms being targeted by activists or the ownership stakes taken by activists. In particular, passive mutual fund ownership does not have a statistically significant association with target firms' cash holdings, dividend yield, leverage ratio, level of capital expenditures or R\&D expenses, return on assets, Tobin's Q, or stock return in the year prior to being targeted. And, the estimates for the size of the activists' ownership stake (as measured by percent holdings) is also unrelated to passive institutional ownership.

\section{Additional robustness checks and alternative mechanisms}

In this section, we discuss the robustness of our IV estimates. In particular, we demonstrate that our findings are not sensitive to only using end-of-May market cap rankings to select our sample of stocks each year, to including additional control variables, to excluding activists that only a file a $13 \mathrm{D}$, to using alternative databases of activism outcomes, or to using alternative definitions of passive ownership.

\subsection{Robustness to alternative sampling choices, controls, and placebo tests}

In our main analysis, we select the sample to be the 500 stocks with the smallest portfolio weights in the Russell 1000 and the 500 stocks with the largest portfolio weights in the Russell 2000. Our findings, however, are not sensitive to instead using end-of-May market caps to determine the sample of stocks each year. In particular, we can rank stocks based on their end-of-May market cap, calculated with data from CRSP, and select the sample for each year using firms ranked $500^{\text {th }}$ through $1,500^{\text {th }}$ in that year. An advantage of this latter approach is that it eliminates the risk that Russell's float-adjusted reweighting of stocks within an index affects our findings. A disadvantage of this approach, however, is that we are no longer necessarily comparing the very bottom firms of the Russell 1000 against the very top firms of the Russell 2000, which is where we would expect to find the biggest difference in passive ownership (and hence, outcomes) to occur. This sampling choice, however, has little impact on our IV estimates. While the first stage estimates are expectedly smaller in magnitude and noisier when we use end-of-May market caps to rank stocks and select our sample each year (coefficient $=0.83, t$-stat $=2.75$ ), the IV estimations are largely unchanged (see Appendix Table 3).

Our findings are also largely unaffected if we add controls to account for a stock's liquidity. If an increase in passive ownership improves a stock's liquidity, then this could be an additional mechanism by which passive ownership affects activism outcomes. However, including controls for both Amihud's 
measure of illiquidity and bid-ask spread has little impact on our findings (see Appendix Table 4). Our findings are also robust to instead controlling for the ratio of float-adjusted market capitalization to total market capitalization rather than controlling for $\operatorname{Ln}($ Float $)$ as in our main analysis. These results suggest that a difference or change in liquidity is unlikely to be the key mechanism by which higher passive ownership affects the strategic choices of activists and the outcomes of their campaigns.

Our findings are also robust to including controls for characteristics of the target company and controls for whether a company's stock switched indexes. If index switchers differ in other dimensions and represent a disproportionate share of either index, this could affect our earlier estimates. However, all of the findings are robust to the inclusion of controls for whether a firm's stock moved from the Russell 1000 to the Russell 2000 that year, and vice versa. Our findings are also robust to including controls for the $t-1$ characteristics of targeted firms, including cash, dividend yield, leverage, the level R\&D expenses and capital expenditures, return on assets, Tobin's $Q$, and stock return.

Our findings are also robust to how we define an activist campaign. Excluding activist campaigns where we only observe the filing of a 13D, but no subsequent information on the tactics employed or changes sought by the activist, which occurs in 67 of our 466 activist campaigns, does not affect our findings. This is shown in Appendix Table 5. Our findings are also robust to combining activist campaigns that occur within the same year. In our main analysis, we treat each activist event reported in SharkWatch as a separate campaign. However, collapsing multiple activist events that occur in the same year into one combined campaign does not qualitatively affect our findings.

Finally, in further support that our findings are not driven by specification error, we do not find an association between passive ownership and our outcomes of interest in placebo IV or reduced-form tests that use alternative thresholds. For example, if we restrict the sample to the top 500 firms of the Russell 2000 , and replace our $R 2000$ indicator with an indicator for the bottom 250 firms of this subsample, as measured using end-of-May market capitalization, our IV estimation does not detect an effect of passive ownership on any of our outcomes. Likewise, we do not find an effect of passive ownership in a similar placebo test that uses the bottom 500 firms of the Russell 1000.

\subsection{Robustness to alternative activism data}

Next, we investigate the robustness of our results to using activism events defined by Brav et al. (2008, 2010). The differences between this database and SharkWatch are discussed in Section 2.4. We consider outcomes from this database that are similar to our main results: board representation is an indicator for if the activist seeks a board seat without a proxy contest; proxy fight is an indicator for the 
activist attempting to replace the board through a proxy fight; win/settlement is an indicator for the activist either winning a proxy fight or achieving a settlement with management; governance objective is an indicator for if the activist seeks governance changes, which include the removal of takeover defenses, $\mathrm{CEO} /$ chairman replacement, board independence, etc.; and takeover is an indicator for a takeover bid.

Panel A of Table 10 reports the effects of passive mutual fund ownership on these outcomes between 2008 and 2014. Consistent with the results in Tables 5-7, we find that passive ownership is associated with an increased likelihood of activists seeking board representation both through non-hostile tactics and hostile tactics (i.e., proxy fights), and an increase in the willingness of managers to settle with activists. We also find that passive ownership is associated with an increase in the likelihood of activists seeking governance reform which mirrors the removal of takeover defenses in Table 8. There is somewhat of a discrepancy, however, for takeovers. Using the SharkWatch data, we find higher passive ownership is associated with an increase in acquisitions by either the activist or a third party (Table 8), but there is no relation between passive ownership and takeover bids using the data from Brav et al. $(2008,2010)$. This discrepancy seems to originate from a difference in how the takeover indicator is defined in the two datasets; Brav et al. measures whether a takeover bid was attempted (Table 10, Column 5), while SharkWatch measures whether a takeover bid was successfully completed (Table 8, Column 1). If we rerun our earlier analysis using takeover outcomes as defined in SharkWatch but restrict our sample to the hedge fund activism events identified in Brav et al., our findings with respect to takeovers are qualitatively similar to those using the full sample. Our other findings from Tables 5-9 are also robust to restricting our SharkWatch data to the hedge fund activist events found in the Brav et al.

Unlike the SharkWatch data, which begins coverage in 2006, the data from Brav et al. $(2008,2010)$, also allows us analyze the importance of passive ownership for activism in earlier years. Panel B of Table 10 reports the effect of passive ownership on the same outcomes for the 1999-2007. We begin this analysis in 1999 since 1998 is the first year in which Russell's float-adjusted market cap is available, and because this sample predates the use of banding by Russell, we exclude the additional banding controls. In contrast to the later time period, we do not find an effect of passive mutual fund ownership on any of the outcomes. The lack of an effect for earlier years is consistent with anecdotal evidence suggesting that passive institutional investors have only become receptive to supporting activists in more recent years.

\subsection{Robustness to alternative definitions of passive ownership}

For our analysis above, we measure the ownership stake of passive investors using the Thomson Reuters S12 mutual fund data. An advantage of using the S12 data is that it allows for a precise measure 
of passive ownership. A disadvantage, however, is that the S12 mutual fund data doesn't include the holdings of passive institutional investors like banks, insurance companies, and pension funds, some of which might also adopt passive investment strategies. To analyze whether our use of mutual fund holdings affects our findings, we rerun our analysis using a broader (but noisier) measure of passive ownership, as constructed from the $13 \mathrm{~F}$ forms reported by institutions.

Any financial institution exercising discretionary management of investment portfolios over $\$ 100$ million in qualified securities is required to report its aggregate holdings quarterly to the SEC using Form 13F. The Thomson Reuters Institutional Holdings (13F) Database captures a larger share of institutional ownership than the S12 data - 13F institutional holdings account for about $65 \%$ of market capitalization compared to the $26.5 \%$ of market capitalization for the S12 mutual fund holdings. Using the 13F data, we classify institutions as either passive or active using Bushee's (2001) classification. In particular, we classify "quasi-index" institutions as passive and "transient" or "dedicated" institutions as active.

Using the broader measure of passive ownership based on the $13 \mathrm{~F}$ filings has no effect on our findings. Using the alternative measure of passive ownership, we repeat our IV estimations, and these are reported in Appendix Table 6. Consistent with the first-stage estimates in Table 3, our first-stage estimates using the $13 \mathrm{~F}$ data are significant only for the "quasi-index" passive investors, but as expected, are also smaller in magnitude and less precisely estimated since "quasi-indexers" also includes the nonpassive holdings of each institution. Despite this limitation, our IV estimates when using "quasi-index" remain qualitatively similar to those reported earlier in Tables 5-9

\section{Conclusion}

Recent years have seen a dramatic rise in the amount, the aggressiveness, and the success rate of activist investing. This increased activism has coincided with the growing influence of passive institutional investors; as of December 2014 passively managed mutual funds account for more than a third of all mutual fund assets. In this paper, we ask whether the growing importance of passive institutional investors has influenced the strategic choices of activists and their success rates.

Our findings suggest that the growth of passive investors facilitates activism by lowering the costs associated with certain activism tactics and by increasing the activists' likelihood of success. Over the 20082014 period we find that higher passive ownership is associated with greater success by activists in obtaining board representation, removing takeover defenses, and facilitating the sale of a targeted company. We find no evidence, however, that passive ownership is related to activist efforts to affect policies, such as changes to payout policy or capital structure, which some passive institutions associate with shorter-term goals that do not necessarily improve long-term value. We also show that the likelihood of activists 
initiating a proxy fight is significantly higher when passive ownership of the stock is higher. Because proxy fights are generally seen as a more expensive form of activism, our findings suggest an increased willingness by activists to pursue more expensive tactics when passive ownership is higher. We find no evidence, however, that higher passive ownership increases the likelihood of an activist campaign or a shift in the type of firms targeted by activists, suggesting these are not the primary mechanism by which passive ownership affects activists' strategic choices.

Given the myriad of agency conflicts that might exist between managers and shareholders, such as a manager's inclination to empire build, to enjoy the quiet life, or to play it safe (e.g., Jensen, 1986; Bertrand and Mullainathan, 2003; Gormley and Matsa, 2016), it is crucial to understand how the shifting nature of U.S. stock ownership affects the ability of shareholders to discipline managers. While some worry that the growth of passive investors weakens firm-level governance, our findings provide evidence to the contrary. Specifically, passive investors have been shown to be strong supporters of good governance practices that are consistent with long-term firm value (Appel, Gormley and Keim, 2016), and we provide evidence here that passive institutional ownership also bolsters the efforts of activists that seek see similar goals. 


\section{References}

Activist Insight, 2014. Activism Monthly (September)

Angrist, J., Pischke, J., 2009. Mostly Harmless Econometrics: An Empiricist's Companion. Princeton University Press, Princeton.

Appel, I., Gormley, T., Keim, D., 2016. Passive investors, not passive owners. Journal of Financial Economics 121, 111-141.

Appel, I., Gormley, T., Keim, D., 2015. Identification using Russell 1000/2000 index assignments: A discussion of methodologies. Working paper.

Bakke, T., Whited, T., 2012. Threshold events and identification: A study of cash shortfalls. Journal of Finance 67, 1083-1111.

Bebchuk, L., 2007. The myth of the shareholder franchise. Virginia Law Review 93, 675-732.

Bebchuk, L., Brav, A., Jiang, W., 2015. The long-term effects of hedge fund activism. Working paper.

Becht, M., Franks, J., Mayer, C., Rossi, S., 2009. Returns to shareholder activism: Evidence from a clinical study of the Hermes UK Focus Fund. Review of Financial Studies 22, 3093-3129.

Bird, A., Karolyi, S., 2016. Do institutional investors demand public disclosure? Review of Financial Studies, forthcoming.

Boone, A., White, J., 2015. The effect of institutional ownership on firm transparency and information production. Journal of Financial Economics 117, 508-533.

Boyson, N., Gantchev, N., Shivdasani, A., 2015. Activism mergers. Working paper.

Boyson, N., Pichler, P., 2016. Hostile resistance to hedge fund activism. Working paper.

Bradley, M., Brav, A., Goldstein, I., Jiang, W., 2010. Activist arbitrage: A study of open-ending attempts of closed-end funds. Journal of Financial Economics 95, 1-19.

Brav, A., Jiang, W., Kim, H., 2010. Hedge fund activism: A review. Foundations and Trends in Finance 4, 1-66.

Brav, A., Jiang, W., Kim, H., 2015. The real effects of hedge fund activism: Productivity, asset allocation, and labor outcomes. Review of Financial Studies 28, 2723-2769.

Brav, A., Jiang, W., Ma S., Tian X., 2014. Shareholder power and corporate innovation: Evidence from hedge fund activism. Working paper.

Brav, A., Jiang, W., Partnoy, F., Thomas, R., 2008. Hedge fund activism, corporate governance, and firm performance. Journal of Finance 63, 1729-1775.

Brav, A., Dasgupta, A., Mathews, R., 2015. Wolf pack activism. Working paper.

Busse, J., Tong, Q., 2012. Mutual fund industry selection and persistence. Review of Asset Pricing Studies 2, 245-274. 
Briggs, T., 2007. Corporate governance and the new hedge fund activism: An empirical analysis. Journal of Corporation Law 32, 681-738.

Chang, Y., Hong, H., Liskovich, I., 2015. Regression discontinuity and the price effects of stock market indexing. Review of Financial Studies 28, 212-246.

Clifford, C., 2008. Value creation or destruction? Hedge funds as shareholder activists. Journal of Corporate Finance 14, 323-336.

Coffee, J., Palia, D., 2015. The wolf at the door: The impact of hedge fund activism on corporate governance. Working paper.

Collin-Dufresne, P. and Fos, V., 2015. Do prices reveal the presence of informed trading? Journal of Finance 70, 1555-1582.

Crane, A., Michenaud, S., Weston, J., 2014. The effect of institutional ownership on payout policy: Evidence from index thresholds. Review of Financial Studies, forthcoming.

Denes, M., Karpoff, J., McWilliams, V., 2015. Thirty years of shareholder activism: A survey of empirical research. Journal of Corporate Finance, forthcoming.

Dimson, E., Karakaş, O., Li, X., 2015. Active ownership. Review of Financial Studies 28, 3225-3268.

Fich, E., Harford, J., Tran, A., 2015. Motivated monitors: The importance of institutional investors' portfolio weights. Journal of Financial Economics 118, 21-48.

Fos, V., 2015. The disciplinary effects of proxy contests. Management Science, forthcoming.

Fos, V., Tsoutsoura, M., 2014. Shareholder democracy in play: Career consequences of proxy contests. Journal of Financial Economics 114, 316-340.

Gantchev, Nickolay, 2013. The costs of shareholder activism: Evidence from a sequential decision model. Journal of Financial Economics 107(3), 610-631.

Gillan, S., Starks, L., 2007. The evolution of shareholder activism in the United States. Journal of Applied Corporate Finance 19, 55-73.

Gompers, P., Ishii, J., Metrick, A., 2010. Extreme governance: an analysis of dual-class firms in the United States. Review of Financial Studies 23, 1051-1088.

Gormley, T., Matsa, D., 2016. Playing it safe? Managerial preferences, risk, and agency conflicts. Journal of Financial Economics, forthcoming.

Greenwood, R., Schor, M., 2009. Investor activism and takeovers. Journal of Financial Economics 92, 362-375.

Guo, R., Kruse, T., Nohel, T., 2008. Undoing the powerful anti-takeover force of staggered boards. Journal of Corporate Finance 14, 274-288.

Iliev, P., Lowry, M., 2015. Are mutual funds active voters? The Review of Financial Studies 28, 446-485.

Investment Technology Group, 2008. 2008 Russell Reconstitution Recap. 
Jensen, M., 1986. Agency costs of free cash flow, corporate finance and takeovers. American Economic Review 76, 323-329.

Klein, A., Zur, E., 2009. Entrepreneurial shareholder activism: Hedge funds and other private investors. Journal of Finance 64, 187-229.

McCahery, J., Sautner, Z., Starks, L., 2015. Behind the scenes: The corporate governance preferences of institutional investors. Journal of Finance, forthcoming.

Mullins, W., 2014. The governance impact of index funds: evidence from a regression discontinuity. Working paper.

Popadak, J., 2013. A corporate culture channel: How increased shareholder governance reduces firm value. Working paper.

Russell Investments, 2013. Russell U.S. Equity Indexes Construction and Methodology.

Schmidt, C., Fahlenbrach, R., 2016. Do exogenous changes in passive institutional ownership affect corporate governance and firm value? Journal of Financial Economics, forthcoming.

Sommer, J., 2013. Challenging management (but not the market). The New York Times, March 16.

Stock, J., Wright, J., Yogo, M., 2002. A survey of weak instruments and weak identification in generalized method of moments, Journal of Business \& Economics Statistics 20, 518-529.

The Economist, 2015. Capitalism's unlikely heroes: Why activist investors are good for the public company, February $7^{\text {th }}$.

Wilcox, J., 2005. Shareholder nominations of corporate directors: Unintended consequences and the case for reform of the U.S. proxy system, in Shareholder Access to the Corporate Ballot, ed. Lucian Bebchuk, Harvard University Press. 
$\%$ of equity mutual fund assets that are passively managed

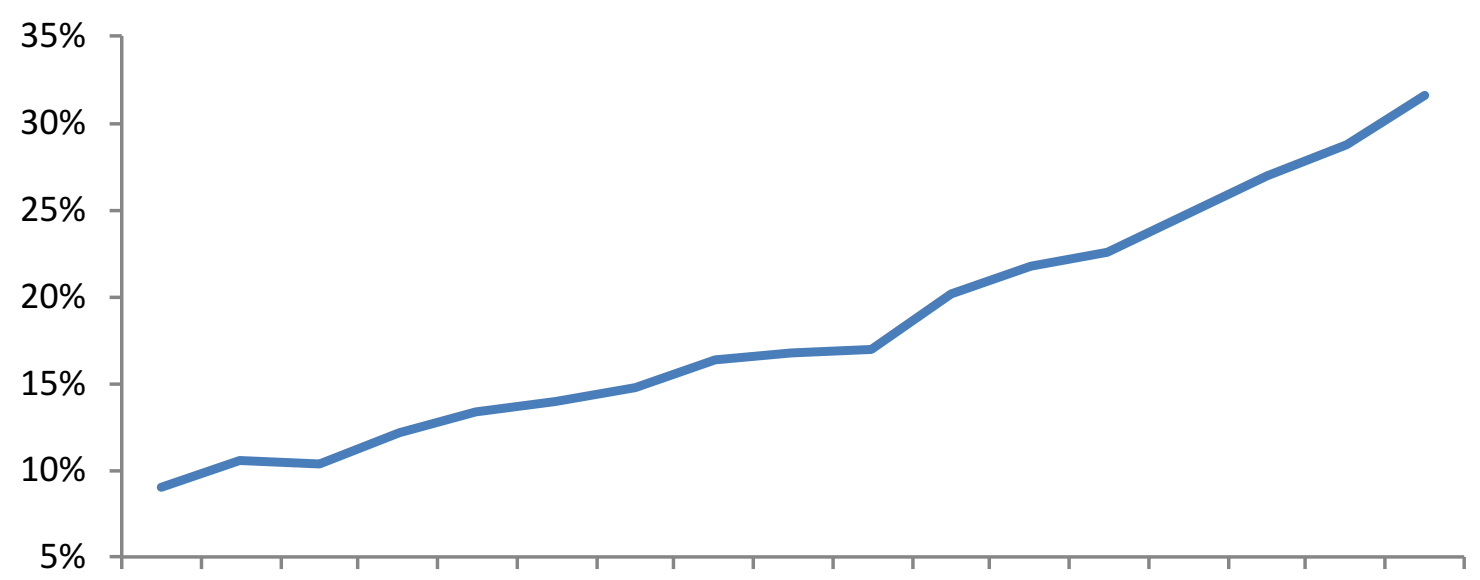

$\%$ of total market cap held by passively managed funds

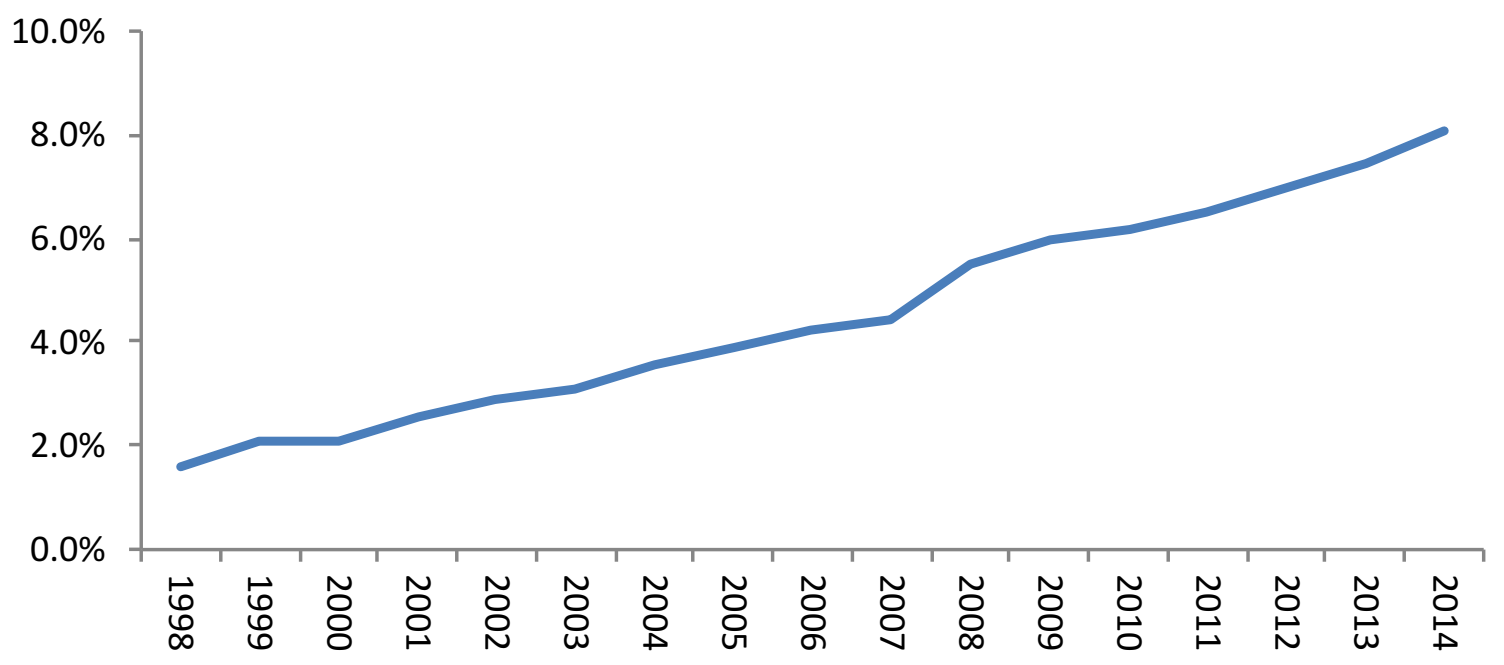

Figure 1

Growth of passive investors, 1998-2014

This figure plots the estimated percent of all U.S. equity mutual fund assets under management between 1998 and 2014 that are held in passively managed funds and the estimated percent of total U.S. market capitalization held by passively managed mutual funds. We construct the figure by matching the S12 mutual fund holdings data compiled in the Thomson Reuters Mutual Fund Holdings Database to market caps reported in CRSP and fund names in the CRSP mutual fund data. We use a name-parsing procedure along with the index fund identifier from the CRSP mutual fund file to classify mutual funds as passively managed. Our procedure is described in the text. Holdings and market cap are calculated each year at the end of the third quarter. 

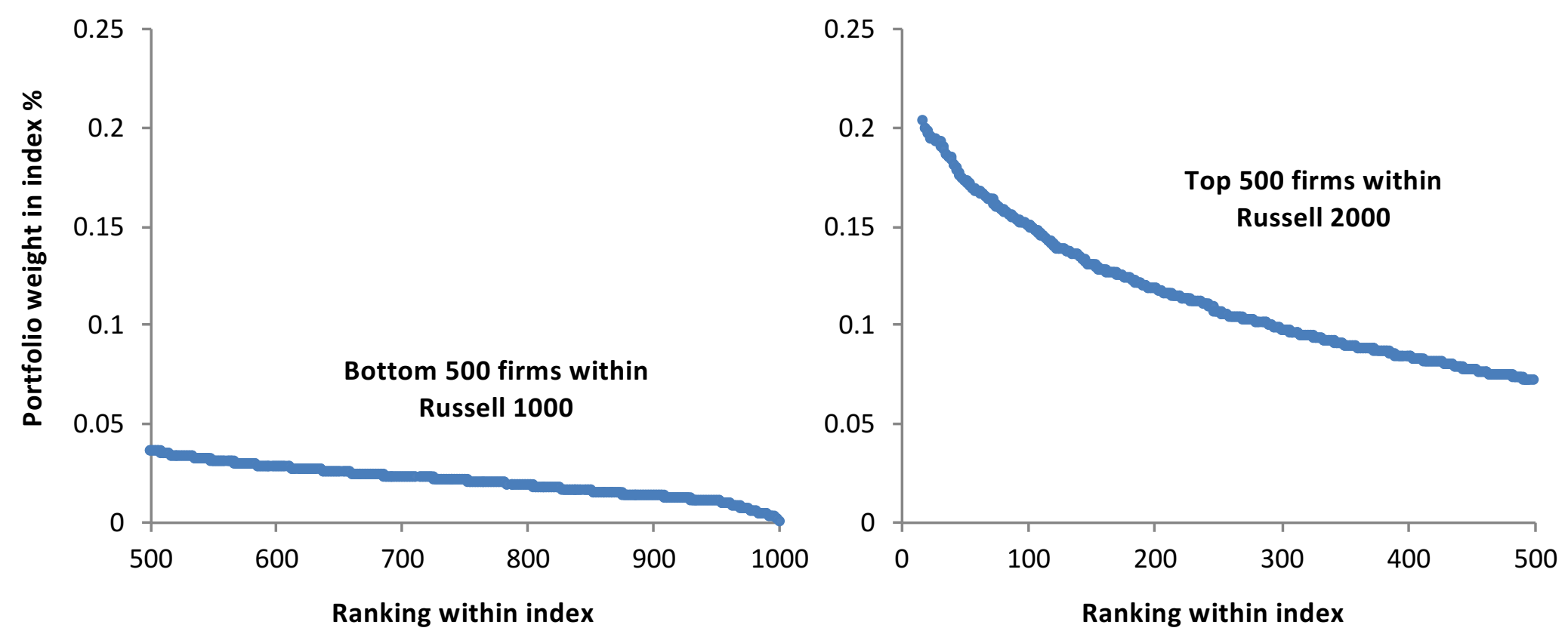

Figure 2

Portfolio weights in the Russell 1000 and 2000 indices by within-index ranking for the year 2013

This figure plots the portfolio weights of the bottom 500 firms in the Russell 1000 index and the top 500 firms in the Russell 2000 index for the end-of-June 2013. Observations are ordered by their within-index ranking such that rankings of 1 and 1,000 represent the firms with the largest and 1,000th largest portfolio weight in the index, respectively. The portfolio weights are given as a percent. 


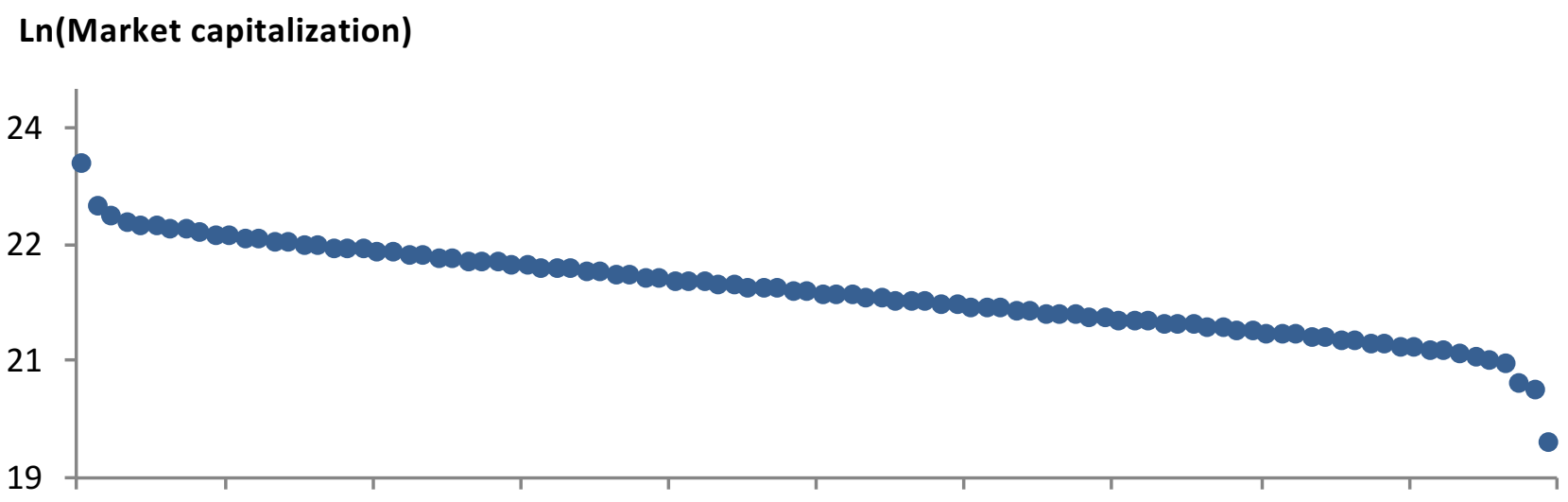

\section{Fraction in Russell 2000}

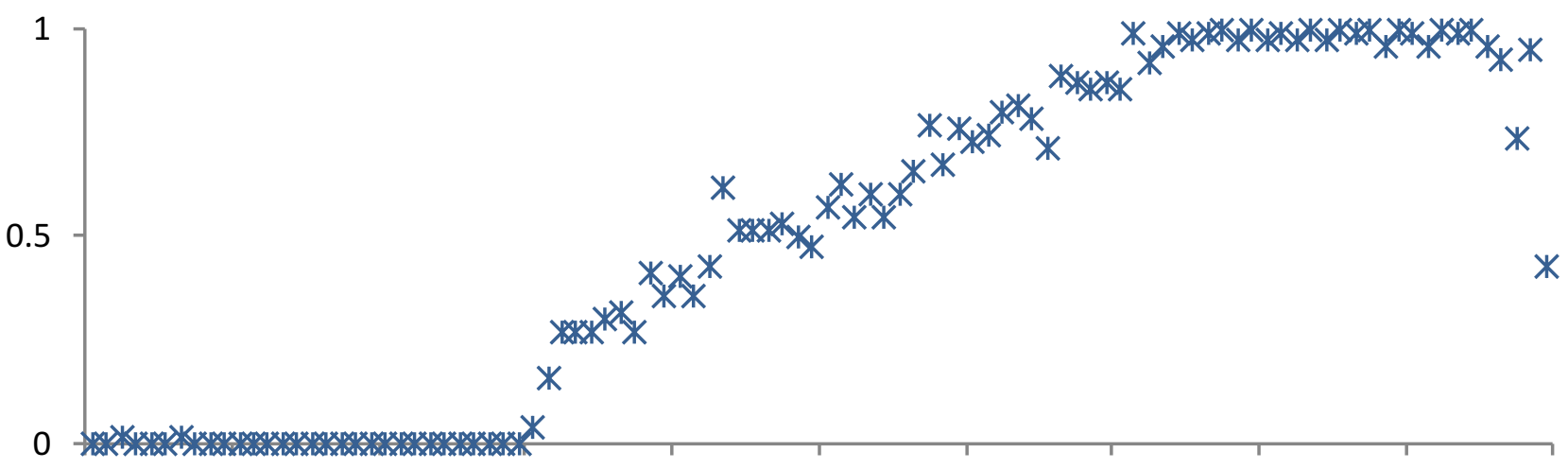

\section{Passive ownership \%}

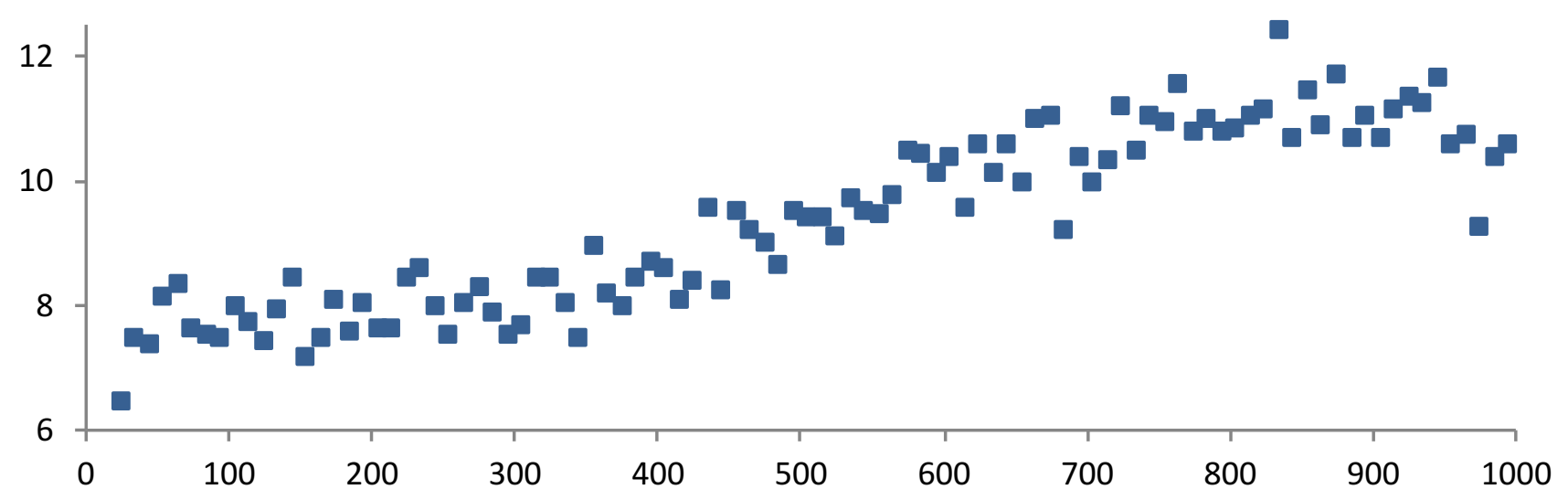

Figure 3

Market capitalization, index assignment, and passive ownership by market capitalization rankings for the bottom 500 firms of Russell 1000 and top 500 firms of Russell 2000

This figure plots the average end-of-May Ln(market capitalization), fraction of firm-year observations in the Russell 2000, and passive mutual fund ownership (\%) by ranking, where ranking is determined using end-ofMay market capitalization, as reported in CRSP. The sample includes the bottom 500 firms of the Russell 1000 and the top 500 firms of the Russell 2000, as determined using end-of-June Russell-assigned portfolio weights for each index. Mutual fund ownership is calculated as of September each year, and all averages are calculated using bins of 10 firms and data from 2007-2013. For the ownership panel, we scale the vertical axis to report two standard deviations on each side of the sample mean. 


\section{Table 1}

\section{Summary statistics}

This table reports summary statistics of our key variables for our main sample: activism events that occur for firms in the 500 bandwidth around the cutoff between the Russell 1000 and 2000 indexes from 2008-2014. Definitions for all variables are provided in Appendix Table 1. We delete observations where either mutual fund ownership is missing or total mutual fund holdings exceed a stock's market capitalization.

\begin{tabular}{lccc}
\hline & Obs. & Mean & SD \\
\hline Ownership structure & & & \\
Total mutual fund ownership \% & 466 & 35.6 & 10.8 \\
Passive ownership \% & 466 & 9.4 & 3.6 \\
Active ownership \% & 466 & 22.7 & 9.7 \\
Unclassified ownership \% & 466 & 3.5 & 2.3 \\
Campaign classifications & & & \\
Seek board representation & & & \\
Maximize value via policy change & 466 & 0.279 & 0.449 \\
Other & 466 & 0.195 & 0.397 \\
13D filing only & 466 & 0.382 & 0.486 \\
& 466 & 0.144 & 0.351 \\
Proxy fight outcomes & & & \\
Proxy fight & & & \\
Seats sought & 466 & 0.189 & 0.392 \\
Proxy fight - settlement & 466 & 0.760 & 1.853 \\
Proxy fight - activist wins & 466 & 0.069 & 0.253 \\
Proxy fight - firm wins & 466 & 0.032 & 0.177 \\
Other outcomes & 466 & 0.034 & 0.182 \\
Acquisition [by third party] & & & \\
Acquisition [by activist] & 466 & 0.024 & 0.152 \\
Merger blocked & 466 & 0.017 & 0.130 \\
Removed takeover defense & 466 & 0.036 & 0.188 \\
Increased payouts & 0.039 & 0.193 \\
Capital structure change & 0.041 & 0.198 \\
Spinoff & & & \\
& 466 & 0.039 & 0.193 \\
& & & \\
\hline
\end{tabular}




\section{Table 2}

\section{Impact of index assignment on mutual fund ownership}

This table reports estimates of a regression of mutual fund holdings on an indicator for membership in the Russell 2000 index plus additional controls. Specifically, we estimate

$$
\text { Ownership } \%_{i t}=\eta+\lambda R 2000_{i t}+\sum_{n=1}^{N} \chi_{n}\left(\text { Ln }\left(\text { Mktcap }_{i t}\right)\right)^{n}+X_{i t}+\text { banding-controls }_{i t}+\delta_{t}+u_{\text {eit }}
$$

where $R 200 O_{i t}$ is a dummy variable equal to 1 if stock $i$ is in the Russell 2000 Index at end of June in year $t$, Mktcap $_{i t}$ is the CRSP market value of equity of stock $i$ measured at May 31 in year $t, N$ is the polynomial order we use to control for $\operatorname{Ln}\left(\right.$ Mktcap $\left._{i t}\right)$, and $\delta_{t}$ are year fixed effects. The estimation includes an additional control for the natural log of the float-adjusted market value of equity on June 30 in year $t, \operatorname{Ln}\left(\right.$ Float $\left._{i t}\right)$. The estimate also includes additional banding controls: an indicator for having an end-of-May market capitalization sufficiently close to the cutoff such that the firm will not switch indexes, band $_{i t}$, an indicator for being in the Russell 2000 last year, $R 2000_{i t \text { - }}$ ${ }_{1}$, and the interaction of these two indicators. Ownership $\%_{i t}$ measures mutual fund ownership (in percent) for stock $i$ at the end of September in year $t$. In this table we use four different definitions for Ownership\% for stock $i$ : (1) the percentage of shares outstanding owned by all mutual funds (from S12 filings); (2) the percentage of shares outstanding owned by passive funds; (3) the percentage of shares outstanding owned by active mutual funds; and (4) the percentage of shares outstanding owned by unclassified mutual funds. The mutual fund classifications are defined in the text. The sample consists of all activism events that target the top 500 firms in the Russell 2000 index and bottom 500 firms of the Russell 1000 index (i.e., bandwidth $=500$ ) over the 2008-2014 period for which we obtain holdings data from Thomson Reuters Mutual Fund Holdings Database and which we match with data from the monthly CRSP file. The model is estimated using a polynomial order control for $\operatorname{Ln}($ Mktcap) of $N=2$. Standard errors, $u$, are clustered at the firm level and reported in parentheses. $* * *$ indicates significance at the $1 \%$ level.

\begin{tabular}{|c|c|c|c|c|}
\hline \multirow{3}{*}{ Dependent variable $=$} & \multicolumn{4}{|c|}{ Percent of firm's common shares held by: } \\
\hline & $\begin{array}{c}\text { All } \\
\text { mutual } \\
\text { funds }\end{array}$ & $\begin{array}{l}\text { Passive } \\
\text { funds }\end{array}$ & $\begin{array}{l}\text { Active } \\
\text { funds }\end{array}$ & $\begin{array}{l}\text { Unclassified } \\
\text { funds }\end{array}$ \\
\hline & $(1)$ & $(2)$ & (3) & $(4)$ \\
\hline \multirow[t]{2}{*}{$R 2000$} & 6.264 & $4.292 * * *$ & 1.670 & 0.302 \\
\hline & $(4.042)$ & $(1.111)$ & $(3.770)$ & $(0.778)$ \\
\hline Polynomial order, $N$ & 2 & 2 & 2 & 2 \\
\hline Banding controls & yes & yes & yes & yes \\
\hline Float control & yes & yes & yes & yes \\
\hline Year fixed effects & yes & yes & yes & yes \\
\hline Observations & 466 & 466 & 466 & 466 \\
\hline$R$-squared & 0.22 & 0.45 & 0.14 & 0.12 \\
\hline
\end{tabular}




\section{Table 3}

\section{First stage estimation for ownership by passively managed funds}

This table reports estimates of our first-stage regression of passive ownership onto an indicator for membership in the Russell 2000 index plus additional controls. Specifically, we estimate

$$
\text { Passive } \left._{i t}=\eta+\lambda R 2000_{i t}+\sum_{n=1}^{N} \chi_{n}\left(\text { Ln }_{\left(\text {Mktcap }_{i t}\right.}\right)\right)^{n}+X_{i t}+\text { banding-controls }_{i t}+\delta_{t}+u_{\text {eit }}
$$

where $R 200 O_{i t}$ is a dummy variable equal to 1 if stock $i$ is in the Russell 2000 Index at end of June in year $t$, Mktcap $_{i t}$ is the CRSP market value of equity of stock $i$ measured at May 31 in year $t, N$ is the polynomial order we use to control for $\operatorname{Ln}\left(\right.$ Mktcap $\left._{i t}\right)$, and $\delta_{t}$ are year fixed effects. The estimation includes an additional control for the natural log of the float-adjusted market value of equity on June 30 in year $t, \operatorname{Ln}\left(\right.$ Float $\left._{i t}\right)$. The estimate also includes additional banding controls: an indicator for having an end-of-May market capitalization sufficiently close to the cutoff such that the firm will not switch indexes, $b_{a n d}$, an indicator for being in the Russell 2000 last year, $R 2000_{i t-1}$, and the interaction of these two indicators. Passive $\%_{i t}$ is the percentage of shares outstanding owned by passively manged mutual funds, as defined in the text, for stock $i$ at the end of September in year $t$ scaled by its sample standard deviation. The sample consists of all activism events that target the top 500 firms in the Russell 2000 index and bottom 500 firms of the Russell 1000 index (i.e., bandwidth $=500$ ) over the 2008-2014 period for which we obtain holdings data from Thomson Reuters Mutual Fund Holdings Database and which we match with data from the monthly CRSP file. The model is estimated using a polynomial order controls for $\operatorname{Ln}($ Mktcap) of $N=1,2$, and 3. Standard errors, $u$, are clustered at the firm level and reported in parentheses. $* * *$ indicates significance at the $1 \%$ level.

\begin{tabular}{|c|c|c|c|c|}
\hline & \multirow[t]{2}{*}{ Dependent variable $=$} & \multicolumn{3}{|c|}{$\begin{array}{c}\text { Passive \% scaled by its } \\
\text { sample standard deviation }\end{array}$} \\
\hline & & $(1)$ & $(2)$ & $(3)$ \\
\hline$R 2000$ & & $\begin{array}{c}0.962 * * * \\
(0.265)\end{array}$ & $\begin{array}{c}1.049 * * * \\
(0.271)\end{array}$ & $\begin{array}{c}1.058 * * * \\
(0.277)\end{array}$ \\
\hline Polynomial order, $N$ & & 1 & 2 & 3 \\
\hline Banding controls & & yes & yes & yes \\
\hline Float control & & yes & yes & yes \\
\hline Year fixed effects & & yes & yes & yes \\
\hline Observations & & 466 & 466 & 466 \\
\hline$R$-squared & & 0.44 & 0.45 & 0.45 \\
\hline
\end{tabular}




\section{Table 4}

\section{Ownership by passive investors and the likelihood of an activist campaign}

This table reports estimates of our instrumental variable estimation used to identify the effect of institutional ownership by passive investors on the likelihood of an activism event. Specifically, we estimate

$$
Y_{\text {eit }+1}=\alpha+\beta \text { Passive }_{i t}+\sum_{n=1}^{N} \theta_{n}(\operatorname{Ln}(\text { Mktcap }))^{n}+X_{i t}+\text { banding-controls }_{i t}+\delta_{t}+\varepsilon_{\text {eit }}
$$

where $Y_{\text {eit }+1}$ is an indicator for the likelihood of an activism event targeting firm $i$ in year $t+1$ scaled by its sample standard deviation, Passive $\%_{i t}$ is the percentage of shares outstanding owned by passively managed mutual funds (as defined in the text) for stock $i$ at the end of September in year $t$ scaled by its sample standard deviation, Mktcap ${ }_{i t}$ is the CRSP market value of equity of stock $i$ measured at May 31 in year $t$, and $\delta_{t}$ are year fixed effects. The estimation includes an additional control for the natural log of the floatadjusted market value of equity on June 30 in year $t, \operatorname{Ln}\left(\right.$ Float $\left._{i t}\right)$. The estimate also includes additional banding controls: an indicator for having an end-of-May market capitalization sufficiently close to the cutoff such that the firm will not switch indexes, band $_{i t}$, an indicator for being in the Russell 2000 last year, $R 2000_{i t-1}$, and the interaction of these two indicators. We instrument Passive\% in the above estimation using $R 2000_{i t}$, an indicator equal to one if firm $i$ is part of the Russell 2000 index in year $t$. The sample consists of the top 500 firms of the Russell 2000 index and bottom 500 firms of the Russell 1000 over the 2008-2014 period for which we obtain holdings data from Thomson Reuters Mutual Fund Holdings Database and which we match with data from the monthly CRSP file. The model is estimated using polynomial order controls $N=1,2$, and 3 for $\operatorname{Ln}($ Mktcap). Standard errors, $\varepsilon$, are clustered at the firm level and reported in parentheses.

\section{Dependent variable $=\quad$ Indicator for an activism campaign}

$(1) \quad(2) \quad(3)$

Passive \%

$-0.017$

$-0.025$

Polynomial order, $N$

$\begin{array}{ccc}1 & 2 & 3 \\ \text { yes } & \text { yes } & \text { yes } \\ \text { yes } & \text { yes } & \text { yes } \\ \text { yes } & \text { yes } & \text { yes }\end{array}$

Banding controls

Float control

Year fixed effects

6,797

6,797

6,797

\section{(3)}

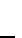




\section{Table 5}

\section{Ownership by passive investors and type of activist campaign}

This table reports estimates of our instrumental variable estimation used to identify the effect of institutional ownership by passive investors on the type of activism campaign. Specifically, we estimate

$$
Y_{\text {eit }+1}=\alpha+\beta \text { Passive }_{i t}+\sum_{n=1}^{N} \theta_{n}(\operatorname{Ln}(\text { Mktcap }))^{n}+X_{i t}+\text { banding-controls }_{i t}+\delta_{t}+\varepsilon_{\text {eit }}
$$

where $Y_{e i t+1}$ is an indicator for the type of campaign for activism event $e$ targeting firm $i$ in year $t+1$ scaled by its sample standard deviation, Passive $\%_{i t}$ is the percentage of shares outstanding owned by passively managed mutual funds (as defined in the text) for stock $i$ at the end of September in year $t$ scaled by its sample standard deviation, Mktcap $_{i t}$ is the CRSP market value of equity of stock $i$ measured at May 31 in year $t$, and $\delta_{t}$ are year fixed effects. The estimation includes an additional control for the natural $\log$ of the float-adjusted market value of equity on June 30 in year $t, \operatorname{Ln}\left(\right.$ Float $\left._{i t}\right)$. The estimate also includes additional banding controls: an indicator for having an end-of-May market capitalization sufficiently close to the cutoff such that the firm will not switch indexes, band $_{i t}$, an indicator for being in the Russell 2000 last year, $R 2000_{i t-1}$, and the interaction of these two indicators. The campaign types investigated in this table, from SharkWatch (Factset), are: an indicator for campaign that seeks board representation (columns 1-3), an indicator for campaigns that seek to maximize shareholder value by advocating for specific corporate policy changes (column 4), an indicator for all other campaign goals (column 5), and an indicator for the campaign only have a 13D filing with no stated intent (column 6). We instrument Passive\% in the above estimation using $R 2000_{i t}$, an indicator equal to one if firm $i$ is part of the Russell 2000 index in year $t$. The sample consists of all activism events that target the top 500 firms in the Russell 2000 index and bottom 500 firms of the Russell 1000 index (i.e., bandwidth = 500) over the 2008-2014 period for which we can obtain holdings data from Thomson Reuters Mutual Fund Holdings Database and which we can match with data from the monthly CRSP file. Standard errors, $\varepsilon$, are clustered at the firm level and reported in parentheses. ** indicates significance at the $5 \%$ level.

\begin{tabular}{|c|c|c|c|c|c|c|}
\hline \multirow[t]{2}{*}{ Dependent variable $=$} & \multicolumn{3}{|c|}{ Seek board representation } & \multirow{2}{*}{$\begin{array}{c}\text { Maximize } \\
\text { value via } \\
\text { policy } \\
\text { change }\end{array}$} & \multirow{2}{*}{$\begin{array}{c}\text { Other } \\
(5) \\
\end{array}$} & \multirow{2}{*}{$\frac{13 \mathrm{D} \text { only }}{(6)}$} \\
\hline & $(1)$ & $(2)$ & $(3)$ & & & \\
\hline Passive \% & $\begin{array}{c}0.731^{* *} \\
(0.338)\end{array}$ & $\begin{array}{c}0.873 * * \\
(0.351)\end{array}$ & $\begin{array}{c}0.884^{* *} \\
(0.351)\end{array}$ & $\begin{array}{l}-0.268 \\
(0.312)\end{array}$ & $\begin{array}{l}-0.642 \\
(0.395)\end{array}$ & $\begin{array}{c}0.077 \\
(0.359)\end{array}$ \\
\hline Polynomial order, $N$ & 1 & 2 & 3 & 2 & 2 & 2 \\
\hline Banding controls & yes & yes & yes & yes & yes & yes \\
\hline Float control & yes & yes & yes & yes & yes & yes \\
\hline Year fixed effects & yes & yes & yes & yes & yes & yes \\
\hline Observations & 466 & 466 & 466 & 466 & 466 & 466 \\
\hline
\end{tabular}




\section{Table 6}

\section{Ownership by passive investors and proxy fight likelihood and board seats sought}

This table reports estimates of our instrumental variable estimation used to identify the effect of institutional ownership by passive investors on the likelihood of a proxy fight and the number of board seats sought by an activist. Specifically, we estimate

$$
Y_{\text {eit }+1}=\alpha+\beta \text { Passive }_{i t}+\sum_{n=1}^{N} \theta_{n}(\operatorname{Ln}(\text { Mktcap }))^{n}+X_{i t}+\text { banding-controls }_{i t}+\delta_{t}+\varepsilon_{\text {eit }}
$$

where $Y_{e i t+1}$ is the outcome of interest for activism event $e$ targeting firm $i$ in year $t+1$ scaled by its sample standard deviation, Passive $\%_{i t}$ is the percentage of shares outstanding owned by passively managed mutual funds (as defined in the text) for stock $i$ at the end of September in year $t$ scaled by its sample standard deviation, Mktcap ${ }_{i t}$ is the CRSP market value of equity of stock $i$ measured at May 31 in year $t$, and $\delta_{t}$ are year fixed effects. The estimation includes an additional control for the natural $\log$ of the float-adjusted market value of equity on June 30 in year $t, \operatorname{Ln}\left(\right.$ Float $\left._{i t}\right)$. The estimate also includes additional banding controls: an indicator for having an end-of-May market capitalization sufficiently close to the cutoff such that the firm will not switch indexes, band $_{i t}$, an indicator for being in the Russell 2000 last year, $R 2000_{i t-1}$, and the interaction of these two indicators. The campaign outcomes investigated in this table, from SharkWatch (Factset), are: an indicator for a proxy fight occuring (columns 1-3) and the number of board seats sought by the activist (columns 4-6). We instrument Passive\% in the above estimation using $R 2000_{i t}$, an indicator equal to one if firm $i$ is part of the Russell 2000 index in year $t$. The sample consists of all activism events that target the top 500 firms in the Russell 2000 index and bottom 500 firms of the Russell 1000 index (i.e., bandwidth $=500$ ) over the 2008-2014 period for which we can obtain holdings data from Thomson Reuters Mutual Fund Holdings Database and which we can match with data from the monthly CRSP file. Standard errors, $\varepsilon$, are clustered at the firm level and reported in parentheses. $* *$ indicates significance at the $5 \%$ level.

\begin{tabular}{|c|c|c|c|c|c|c|}
\hline \multirow{2}{*}{ Dependent variable $=$} & \multicolumn{3}{|c|}{ Proxy fight } & \multicolumn{3}{|c|}{ Number of seats sought } \\
\hline & $(1)$ & (2) & (3) & (4) & $(5)$ & $(6)$ \\
\hline Passive \% & $\begin{array}{c}0.867 * * \\
(0.346)\end{array}$ & $\begin{array}{c}0.884 * * \\
(0.344)\end{array}$ & $\begin{array}{c}0.853 * * \\
(0.334)\end{array}$ & $\begin{array}{c}0.580 * * \\
(0.281)\end{array}$ & $\begin{array}{c}0.571^{* *} \\
(0.276)\end{array}$ & $\begin{array}{c}0.574 * * \\
(0.274)\end{array}$ \\
\hline Polynomial order, $N$ & 1 & 2 & 3 & 1 & 2 & 3 \\
\hline Banding controls & yes & yes & yes & yes & yes & yes \\
\hline Float control & yes & yes & yes & yes & yes & yes \\
\hline Year fixed effects & yes & yes & yes & yes & yes & yes \\
\hline Observations & 466 & 466 & 466 & 466 & 466 & 466 \\
\hline
\end{tabular}




\section{Table 7}

\section{Ownership by passive investors and proxy fight outcomes}

This table reports estimates of our instrumental variable estimation used to identify the effect of institutional ownership by passive investors on proxy fight outcomes. Specifically, we estimate

$$
Y_{\text {eit }+1}=\alpha+\beta \text { Passive }_{i t}+\sum_{n=1}^{N} \theta_{n}(\operatorname{Ln}(\text { Mktcap }))^{n}+X_{i t}+\text { banding-controls }_{i t}+\delta_{t}+\varepsilon_{\text {eit }}
$$

where $Y_{\text {eit }+1}$ is an indicator for the proxy fight outcome for activism event $e$ targeting firm $i$ in year $t+1$ scaled by its sample standard deviation, Passive $\%_{i t}$ is the percentage of shares outstanding owned by passively managed mutual funds (as defined in the text) for stock $i$ at the end of September in year $t$ scaled by its sample standard deviation, Mktcap $_{i t}$ is the CRSP market value of equity of stock $i$ measured at May 31 in year $t$, and $\delta_{t}$ are year fixed effects. The estimation includes an additional control for the natural log of the float-adjusted market value of equity on June 30 in year $t, \operatorname{Ln}\left(\right.$ Float $\left._{i t}\right)$. The estimate also includes additional banding controls: an indicator for having an end-of-May market capitalization sufficiently close to the cutoff such that the firm will not switch indexes, band $_{i t}$, an indicator for being in the Russell 2000 last year, $R 2000_{i t-1}$, and the interaction of these two indicators. The proxy fight outcomes investigated in this table, from SharkWatch (Factset), are: an indicator for a proxy settlement between the firm and the activist (columns 1-3), the activist winning the vote in a proxy fight (column 4), and the firm winning the vote in a proxy fight (column 5). We instrument Passive\% in the above estimation using $R 2000_{i t}$, an indicator equal to one if firm $i$ is part of the Russell 2000 index in year $t$. The sample consists of all activism events that target the top 500 firms in the Russell 2000 index and bottom 500 firms of the Russell 1000 index (i.e., bandwidth $=500$ ) over the 2008-2014 period for which we can obtain holdings data from Thomson Reuters Mutual Fund Holdings Database and which we can match with data from the monthly CRSP file. Standard errors, $\varepsilon$, are clustered at the firm level and reported in parentheses. ** indicates significance at the $5 \%$ level.

\begin{tabular}{|c|c|c|c|c|c|}
\hline \multirow[t]{2}{*}{ Dependent variable $=$} & \multicolumn{3}{|c|}{ Proxy fight settlement } & \multirow{2}{*}{$\begin{array}{c}\text { Activist } \\
\text { wins }\end{array}$} & \multirow{2}{*}{$\begin{array}{c}\text { Firm } \\
\text { wins }\end{array}$} \\
\hline & $(1)$ & $(2)$ & $(3)$ & & \\
\hline Passive \% & $\begin{array}{c}0.760 * * \\
(0.379)\end{array}$ & $\begin{array}{c}0.925^{* *} \\
(0.407)\end{array}$ & $\begin{array}{c}0.889 * * \\
(0.395)\end{array}$ & $\begin{array}{c}0.245 \\
(0.306)\end{array}$ & $\begin{array}{c}0.085 \\
(0.225)\end{array}$ \\
\hline Polynomial order, $N$ & 1 & 2 & 3 & 2 & 2 \\
\hline Banding controls & yes & yes & yes & yes & yes \\
\hline Float control & yes & yes & yes & yes & yes \\
\hline Year fixed effects & yes & yes & yes & yes & yes \\
\hline Observations & 466 & 466 & 466 & 466 & 466 \\
\hline
\end{tabular}




\section{Table 8}

\section{Ownership by passive investors and non-proxy fight activist outcomes}

This table reports estimates of our instrumental variable estimation used to identify the effect of institutional ownership by passive investors on non-proxy fight activist outcomes. Specifically, we estimate

$$
Y_{\text {eit }+1}=\alpha+\beta \text { Passive }_{i t}+\sum_{n=1}^{N} \theta_{n}(\operatorname{Ln}(\text { Mktcap }))^{n}+X_{i t}+\text { banding-controls }_{i t}+\delta_{t}+\varepsilon_{\text {eit }}
$$

where $Y_{\text {eit }+1}$ is an indicator for the outcome of activism event $e$ targeting firm $i$ in year $t+1$ scaled by its sample standard deviation, Passive $\%_{i t}$ is the percentage of shares outstanding owned by passively managed mutual funds (as defined in the text) for stock $i$ at the end of September in year $t$ scaled by its sample standard deviation, Mktcap $_{i t}$ is the CRSP market value of equity of stock $i$ measured at May 31 in year $t$, and $\delta_{t}$ are year fixed effects. The estimation includes an additional control for the natural log of the float-adjusted market value of equity on June 30 in year $t, \operatorname{Ln}\left(\right.$ Float $\left._{i t}\right)$. The estimate also includes additional banding controls: an indicator for having an end-of-May market capitalization sufficiently close to the cutoff such that the firm will not switch indexes, $b_{a n d}{ }_{i t}$, an indicator for being in the Russell 2000 last year, $R 2000_{i t-1}$, and the interaction of these two indicators. The campaign outcomes investigated in this table, from SharkWatch (Factset), are: an indicator for whether the firm is acquired by a third party (column 1), is acquired by the activist (column 2), has a merger blocked (column 3), removes a takeover defense (column 4), increases its payout policy (column 5), makes a change to its capital structure (column 6), or does a spinoff or divestiture (column 7). We instrument Passive\% in the above estimation using $R 2000_{i t}$, an indicator equal to one if firm $i$ is part of the Russell 2000 index in year $t$. The sample consists of all activism events that target the top 500 firms in the Russell 2000 index and bottom 500 firms of the Russell 1000 index (i.e., bandwidth = 500) over the 2008-2014 period for which we can obtain holdings data from Thomson Reuters Mutual Fund Holdings Database and which we can match with data from the monthly CRSP file. Standard errors, $\varepsilon$, are clustered at the firm level and reported in parentheses. * indicates significance at the $10 \%$ level.

\begin{tabular}{|c|c|c|c|c|c|c|c|}
\hline \multirow{3}{*}{ Dep. variable $=$} & \multicolumn{4}{|c|}{ Corporate control and governance outcomes } & \multicolumn{3}{|c|}{ Other corporate policy outcomes } \\
\hline & $\begin{array}{c}\text { Acquired } \\
\text { [by third } \\
\text { party] }\end{array}$ & $\begin{array}{c}\text { Acquired } \\
\text { [by } \\
\text { activist] }\end{array}$ & $\begin{array}{l}\text { Merger } \\
\text { blocked }\end{array}$ & $\begin{array}{c}\text { Removed } \\
\text { takeover } \\
\text { defense }\end{array}$ & $\begin{array}{c}\text { Increased } \\
\text { payouts }\end{array}$ & $\begin{array}{c}\text { Capital } \\
\text { structure } \\
\text { change }\end{array}$ & Spinoff \\
\hline & $(1)$ & $(2)$ & $(3)$ & $(4)$ & $(5)$ & $(6)$ & $(7)$ \\
\hline Passive \% & $\begin{array}{c}0.855^{*} \\
(0.506)\end{array}$ & $\begin{array}{l}0.527 * \\
(0.281)\end{array}$ & $\begin{array}{c}-1.063^{*} \\
(0.572)\end{array}$ & $\begin{array}{l}0.362 * \\
(0.215)\end{array}$ & $\begin{array}{c}0.317 \\
(0.226)\end{array}$ & $\begin{array}{l}-0.237 \\
(0.244)\end{array}$ & $\begin{array}{l}-0.141 \\
(0.281)\end{array}$ \\
\hline Polynomial order, $N$ & 2 & 2 & 2 & 2 & 2 & 2 & 2 \\
\hline Banding controls & yes & yes & yes & yes & yes & yes & yes \\
\hline Float control & yes & yes & yes & yes & yes & yes & yes \\
\hline Year fixed effects & yes & yes & yes & yes & yes & yes & yes \\
\hline Observations & 466 & 466 & 466 & 466 & 466 & 466 & 466 \\
\hline
\end{tabular}




\section{Table 9}

\section{Ownership by passive investors and other activist tactics}

This table reports estimates of our instrumental variable estimation used to identify the effect of institutional ownership by passive investors on the tactics of activism campaigns. Specifically, we estimate

$$
Y_{\text {eit }+1}=\alpha+\beta \text { Passive }_{i t}+\sum_{n=1}^{N} \theta_{n}(\operatorname{Ln}(\text { Mktcap }))^{n}+X_{i t}+\text { banding-controls }_{i t}+\delta_{t}+\varepsilon_{\text {eit }}
$$

where $Y_{e i t+1}$ is an indicator for whether certain activism tactics were used in event $e$ targeting firm $i$ in year $t+1$ scaled by its sample standard deviation, Passive $\%_{i t}$ is the percentage of shares outstanding owned by passively managed mutual funds (as defined in the text) for stock $i$ at the end of September in year $t$ scaled by its sample standard deviation, Mktcap ${ }_{i t}$ is the CRSP market value of equity of stock $i$ measured at May 31 in year $t$, and $\delta_{t}$ are year fixed effects. The estimation includes an additional control for the natural $\log$ of the float-adjusted market value of equity on June 30 in year $t, \operatorname{Ln}\left(\right.$ Float $\left._{i t}\right)$. The estimate also includes additional banding controls: an indicator for having an end-of-May market capitalization sufficiently close to the cutoff such that the firm will not switch indexes, band $_{i}$, an indicator for being in the Russell 2000 last year, $R 2000_{i t-1}$, and the interaction of these two indicators. The activism tactics investigated in this table, from SharkWatch (Factset), are: an indicator for initiating a lawsuit (column 1), writing a non-proxy letter to shareholders or the board (column 2), offering a precatory shareholder proposal (column 3), pushing for a vote on a binding proposal (column 4), or seeking reimbursement (column 5). We instrument Passive\% in the above estimation using $R 2000_{i t}$, an indicator equal to one if firm $i$ is part of the Russell 2000 index in year $t$. The sample consists of all activism events that target the top 500 firms in the Russell 2000 index and bottom 500 firms of the Russell 1000 index (i.e., bandwidth $=500$ ) over the 2008-2014 period for which we can obtain holdings data from Thomson Reuters Mutual Fund Holdings Database and which we can match with data from the monthly CRSP file. Standard errors, $\varepsilon$, are clustered at the firm level and reported in parentheses. * indicates significance at the $10 \%$ level.

\begin{tabular}{|c|c|c|c|c|c|}
\hline Dependent variable $=$ & Lawsuit & $\begin{array}{l}\text { Letter to SH } \\
\text { (non-proxy) }\end{array}$ & $\begin{array}{r}\text { Precatory } \\
\text { proposal }\end{array}$ & $\begin{array}{l}\text { Binding } \\
\text { proposal }\end{array}$ & $\begin{array}{c}\text { Seek } \\
\text { reiumburse- } \\
\text { ment }\end{array}$ \\
\hline & (1) & $(2)$ & (3) & (4) & $(5)$ \\
\hline Passive \% & $\begin{array}{c}0.593 \\
(0.382)\end{array}$ & $\begin{array}{l}-0.583 \\
(0.397)\end{array}$ & $\begin{array}{l}-0.328 \\
(0.358)\end{array}$ & $\begin{array}{c}0.218 \\
(0.395)\end{array}$ & $\begin{array}{l}0.621^{*} \\
(0.339)\end{array}$ \\
\hline Polynomial order, $N$ & 2 & 2 & 2 & 2 & 2 \\
\hline Banding controls & yes & yes & yes & yes & yes \\
\hline Float control & yes & yes & yes & yes & yes \\
\hline Year fixed effects & yes & yes & yes & yes & yes \\
\hline Observations & 466 & 466 & 466 & 466 & 466 \\
\hline
\end{tabular}




\section{Table 10}

\section{Ownership by passive investors and other activist outcomes using Brav, et al data}

This table reports estimates of our instrumental variable estimation used to identify the effect of institutional ownership by passive investors on the tactics of activism campaigns using the extended data of Brav et al. (2008, 2010). Specifically, we estimate

$$
Y_{\text {eit }+1}=\alpha+\beta \text { Passive }_{i t}+\sum_{n=1}^{N} \theta_{n}(\operatorname{Ln}(\text { Mktcap }))^{n}+X_{i t}+\text { banding-controls } s_{i t}+\delta_{t}+\varepsilon_{\text {eit }}
$$

where $Y_{e i t+l}$ is an indicator for either a goal, tactic, or objective of activism event $e$ targeting firm $i$ in year $t+1$ scaled by its sample standard deviation, Passive $\%_{i t}$ is the percentage of shares outstanding owned by passively managed mutual funds (as defined in the text) for stock $i$ at the end of September in year $t$ scaled by its sample standard deviation, Mktcap ${ }_{i t}$ is the CRSP market value of equity of stock $i$ measured at May 31 in year $t$, and $\delta_{t}$ are year fixed effects. The estimation includes an additional control for the natural log of the float-adjusted market value of equity on June 30 in year $t, \operatorname{Ln}\left(\right.$ Float $\left._{i t}\right)$. The estimate in Panel A also includes additional banding controls: an indicator for having an end-of-May market capitalization sufficiently close to the cutoff such that the firm will not switch indexes, $b_{a n d}$, an indicator for being in the Russell 2000 last year, $R 200 O_{i t \text { - }}$ ${ }_{1}$, and the interaction of these two indicators. The campaign outcomes investigated in this table, from Brav, et al (2008; 2010), are: an indicator for if the activist seeks a board seat without a proxy contest (column 1); an indicator for whether the activist initiates a proxy fight (column 2); an indicator for either the activist winning outright or management settling with the activist rather than accommodating, fighting, or ignoring (column 3); an indicator for if the activist targets takeover defenses, CEO/chairman replacement, board independence, etc. (column 4); and an indicator for a takeover bid (column 5). We instrument Passive\% in the above estimation using $R 2000_{i t}$, an indicator equal to one if firm $i$ is part of the Russell 2000 index in year $t$. The sample in Panel A consists of all activism events that target the top 500 firms in the Russell 2000 index and bottom 500 firms of the Russell 1000 index (i.e., bandwidth $=500$ ) over the 2008-2014 period for which we can obtain holdings data from Thomson Reuters Mutual Fund Holdings Database and which we can match with data from the monthly CRSP file, and the sample in Panel B consists of activism events that target the top 500 firms in the Russell index and bottom 500 firms of the Russell 1000 index over the 1999-2007 period. The model is estimated using second-order polynomial controls for $\operatorname{Ln}(M k t c a p)$. Standard errors, $\varepsilon$, are clustered at the firm level and reported in parentheses. ***, **, and * indicate significance at the $1 \%, 5 \%$, and $10 \%$ levels, respectively.

\begin{tabular}{|c|c|c|c|c|c|}
\hline Dep. variable $=$ & $\begin{array}{c}\text { Board } \\
\text { representation }\end{array}$ & Proxy & $\begin{array}{c}\text { Win or } \\
\text { settlement } \\
\text { outcome }\end{array}$ & $\begin{array}{c}\text { Governance } \\
\text { objective }\end{array}$ & $\begin{array}{c}\text { Takeover } \\
\text { bid }\end{array}$ \\
\hline & (1) & (2) & (3) & (4) & (5) \\
\hline
\end{tabular}

Panel A: Activism events, 2008-2014

$\begin{array}{lccccc}\text { Passive \% } & 1.038^{* *} & 0.838^{*} & 1.096^{* *} & 0.759^{*} & -0.909 \\ & (0.416) & (0.494) & (0.441) & (0.413) & (0.635) \\ \text { Polynomial order, } N & 2 & 2 & 2 & 2 & 2 \\ \text { Banding controls } & \text { yes } & \text { yes } & \text { yes } & \text { yes } & \text { yes } \\ \text { Float control } & \text { yes } & \text { yes } & \text { yes } & \text { yes } & \text { yes } \\ \text { Year fixed effects } & \text { yes } & \text { yes } & \text { yes } & \text { yes } & \text { yes } \\ \text { Observations } & 164 & 164 & 164 & 164 & 164\end{array}$


Panel B: Activism events, 1999-2007

\begin{tabular}{lccccc} 
Passive \% & -0.199 & 0.104 & -0.538 & 0.067 & 0.245 \\
& $(0.387)$ & $(0.320)$ & $(0.398)$ & $(0.351)$ & $(0.264)$ \\
Polynomial order, $N$ & & & & & \\
Banding controls & 2 & 2 & 2 & 2 & 2 \\
Float control & yes & yes & yes & yes & yes \\
Year fixed effects & yes & yes & yes & yes & yes \\
Observations & yes & yes & yes & yes & yes \\
& 225 & 225 & 225 & 225 & 225 \\
\hline
\end{tabular}




\section{Appendix Table 1 Variable definitions}

\begin{tabular}{|c|c|c|}
\hline Variable Name & Source & Definition \\
\hline$R 2000$ & Russell Investments & Indicator equal to 1 if firm is in the Russell 2000 \\
\hline Mutual fund ownership \% & Thomson Reuters S12 files & $\%$ of shares outstanding held by mutual funds in September of year $t$ \\
\hline Passive \% & Thomson Reuters S12 files & $\%$ of shares outstanding held in September of year $t$ by passively managed funds \\
\hline Active \% & Thomson Reuters S12 files & $\%$ of shares outstanding held in September of year $t$ by actively managed funds \\
\hline Unclassified \% & Thomson Reuters S12 files & $\%$ of shares outstanding held in September of year $t$ by unclassified funds \\
\hline Seek board representation & SharkWatch (FactSet) & Indiator equal to 1 if campaign seeks board representation for activist \\
\hline Max. value via policy change & SharkWatch (FactSet) & Indiator equal to 1 if campaign specifically seeks to maximize firm value \\
\hline Other & SharkWatch (FactSet) & Indiator equal to 1 if campaign does not seek board representation or to maximize firm value \\
\hline $13 D$ only & SharkWatch (FactSet) & Indiator equal to 1 if campaign only consists of 13D filing with no stated goal \\
\hline Proxy fight & SharkWatch (FactSet) & Indiator equal to 1 if campaign includes a proxy fight \\
\hline Number of seats sought & SharkWatch (FactSet) & Number of board seats sought by activist in campaign \\
\hline Proxy fight - settlement & SharkWatch (FactSet) & Indiator equal to 1 if proxy fight is settled \\
\hline Proxy fight - activist wins & SharkWatch (FactSet) & Indiator equal to 1 if activist wins proxy fight \\
\hline Proxy fight - firm wins & SharkWatch (FactSet) & Indiator equal to 1 if firm wins proxy fight \\
\hline Acquisition by other party & SharkWatch (FactSet) & Indiator equal to 1 if campaign succesfully seeks and obtains an acquisition by a third party \\
\hline Acquisition by activist & SharkWatch (FactSet) & Indiator equal to 1 if campaign succesfully seeks an obtains an acquisition by the activist \\
\hline Merger blocked & SharkWatch (FactSet) & Indiator equal to 1 if campaign succesfully seeks to block a merger or agitate for higher price \\
\hline Removed takeover defense & SharkWatch (FactSet) & Indiator equal to 1 if campaign succesfully seeks and obtains removal of takeover defenses \\
\hline Increase payouts & SharkWatch (FactSet) & Indiator equal to 1 if campaign succesfully seeks increased payouts to shareholders \\
\hline Capital structure change & SharkWatch (FactSet) & Indiator equal to 1 if campaign succesfully seeks a change in capital structure \\
\hline Spinoff and/or divestiture & SharkWatch (FactSet) & Indiator equal to 1 if campaign succesfully seeks a spinoff or divestiture \\
\hline Lawsuit & SharkWatch (FactSet) & Indiator equal to 1 if campaign features a lawsuit \\
\hline Precatory proposal & SharkWatch (FactSet) & Indiator equal to 1 if campaign features a non-binding proposal \\
\hline Binding proposal & SharkWatch (FactSet) & Indiator equal to 1 if campaign features a binding proposal \\
\hline Letter (non-proxy) & SharkWatch (FactSet) & Indiator equal to 1 if campaign issues a non-proxy fight related letter to the board or shareholders \\
\hline
\end{tabular}


Seek reimbursement

Board representation

Proxy

Win or settlement outcome

Governance objective

Takeover bid
SharkWatch (FactSet)

Brav et al. (2008, 2010)

Brav et al. (2008, 2010)

Brav et al. (2008, 2010)

Brav et al. (2008, 2010)

Brav et al. (2008, 2010)
Indiator equal to 1 if campaign seeks reimbursement from firm

Indiator equal to 1 if campaign seeks board representation without proxy contest

Indiator equal to 1 if campaign involves proxy contest

Indiator equal to 1 if campaign outcome is either a success or settlement

Indiator equal to 1 if campaign has a governance objective as defined by Brav et al $(2008,2010)$

Indiator equal to 1 if campaign involves a takeover bid by the activist 


\section{Appendix Table 2}

First stage estimation for ownership by actively managed and unclassified mutual funds

This table reports estimates of our first-stage regression of ownership by actively managed and unclassified mutual funds onto an indicator for membership in the Russell 2000 index plus additional controls over the 2008-2014 sample period. The specification is the same as in Table 3, except that the dependent variable in columns (1)-(3) is now Active $\%_{i}$, which is the percentage of shares outstanding owned by actively managed mutual funds for stock $i$ at the end of September in year $t$ scaled by its sample standard deviation, and the dependent variable in columns (4)-(6) is now Unclassified $\%_{i t}$, which is the percentage of shares outstanding owned by unclassified mutual funds for stock $i$ at the end of September in year $t$ scaled by its sample standard deviation. Both Active\% and Unclassified\% are defined in the text. Standard errors are clustered at the firm level and reported in parentheses.

\begin{tabular}{|c|c|c|c|c|c|c|}
\hline \multirow[t]{2}{*}{ Dependent variable $=$} & \multicolumn{3}{|c|}{$\begin{array}{c}\text { Active \% scaled by its } \\
\text { sample standard deviation }\end{array}$} & \multicolumn{3}{|c|}{$\begin{array}{l}\text { Unclassified \% scaled by its } \\
\text { sample standard deviation }\end{array}$} \\
\hline & $(1)$ & $(2)$ & (3) & $(4)$ & $(5)$ & (6) \\
\hline$R 2000$ & $\begin{array}{l}-0.152 \\
(0.358)\end{array}$ & $\begin{array}{c}0.164 \\
(0.370)\end{array}$ & $\begin{array}{c}0.172 \\
(0.380)\end{array}$ & $\begin{array}{c}0.184 \\
(0.252)\end{array}$ & $\begin{array}{c}0.113 \\
(0.291)\end{array}$ & $\begin{array}{c}0.208 \\
(0.280)\end{array}$ \\
\hline Polynomial order, $N$ & 1 & 2 & 3 & 1 & 2 & 3 \\
\hline Banding controls & yes & yes & yes & yes & yes & yes \\
\hline Float control & yes & yes & yes & yes & yes & yes \\
\hline Year fixed effects & yes & yes & yes & yes & yes & yes \\
\hline Observations & 466 & 466 & 466 & 466 & 466 & 466 \\
\hline R-squared & 0.11 & 0.14 & 0.14 & 0.12 & 0.12 & 0.13 \\
\hline
\end{tabular}




\section{Appendix Table 3}

\section{Robustness of findings to selecting sample only using end-of-May market cap rankings}

This table reports estimates of the second-stage regression of our instrumental variable estimation to identify the effect of institutional ownership by passive investors on our activism outcome variables when we select our sample using firms with an end-of-May market cap ranking between 500 and 1500. The estimation and outcomes are the same as in Tables 5-9. We instrument Passive\% using $R 2000_{i t}$, an indicator equal to one if firm $i$ is part of the Russell 2000 index in year $t$. The model is estimated using activism campaigns over the 2008-2014 period that target firms in the selected sample and includes a second-order polynomial control for $\operatorname{Ln}(\mathbf{M k t c a p})$. Standard errors, $\varepsilon$, are clustered at the firm level and reported in parentheses. * and ** indicate significance at the $10 \%$ and $5 \%$ levels, respectively.

\begin{tabular}{|c|c|c|c|c|c|c|c|c|}
\hline \multirow{3}{*}{ Dep. variable $=$} & \multicolumn{4}{|c|}{ Board related tactics and outcomes } & \multicolumn{4}{|c|}{ Other outcomes } \\
\hline & $\begin{array}{c}\text { Seek } \\
\text { board } \\
\text { rep. }\end{array}$ & $\begin{array}{l}\text { Proxy } \\
\text { fight }\end{array}$ & $\begin{array}{l}\text { Seats } \\
\text { sought }\end{array}$ & $\begin{array}{c}\text { Proxy } \\
\text { settlement }\end{array}$ & $\begin{array}{c}\text { Acquired } \\
\text { [by third } \\
\text { party] }\end{array}$ & $\begin{array}{c}\text { Acquired } \\
\text { [by } \\
\text { activist] }\end{array}$ & $\begin{array}{l}\text { Merger } \\
\text { blocked }\end{array}$ & $\begin{array}{c}\text { Removed } \\
\text { takeover } \\
\text { defense }\end{array}$ \\
\hline & $(1)$ & $(2)$ & (3) & $(4)$ & (5) & $(6)$ & $(7)$ & $(8)$ \\
\hline Passive \% & $\begin{array}{l}0.905^{*} \\
(0.462)\end{array}$ & $\begin{array}{l}0.781^{*} \\
(0.408)\end{array}$ & $\begin{array}{l}0.616^{*} \\
(0.336)\end{array}$ & $\begin{array}{l}0.894 * \\
(0.488)\end{array}$ & $\begin{array}{c}0.798 \\
(0.543)\end{array}$ & $\begin{array}{c}0.258 \\
(0.427)\end{array}$ & $\begin{array}{c}-1.608^{* *} \\
(0.758)\end{array}$ & $\begin{array}{c}0.576 \\
(0.369)\end{array}$ \\
\hline Polynomial order, $N$ & 2 & 2 & 2 & 2 & 2 & 2 & 2 & 2 \\
\hline Banding controls & yes & yes & yes & yes & yes & yes & yes & yes \\
\hline Float control & yes & yes & yes & yes & yes & yes & yes & yes \\
\hline Year fixed effects & yes & yes & yes & yes & yes & yes & yes & yes \\
\hline Observations & 454 & 454 & 454 & 454 & 454 & 454 & 454 & 454 \\
\hline
\end{tabular}




\section{Appendix Table 4}

\section{Robustness of findings to controlling for liquidity}

This table reports estimates of the second-stage regression of our instrumental variable estimation to identify the effect of institutional ownership by passive investors on our activism outcome variables when we add controls for liquidity. The estimation and outcomes are the same as in Tables 5-9, except we include two additional controls

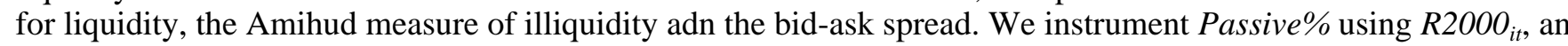
indicator equal to one if firm $i$ is part of the Russell 2000 index in year $t$. The model is estimated using activism campaigns that target firms in the selected sample over the 2008-2014 period and includes a second-order polynomial control for $\operatorname{Ln}($ Mktcap). Standard errors, $\varepsilon$, are clustered at the firm level and reported in parentheses. $*$ and ${ }^{* *}$ indicate significance at the $10 \%$ and $5 \%$ levels, respectively.

\begin{tabular}{|c|c|c|c|c|c|c|c|c|}
\hline \multirow{3}{*}{ Dep. variable $=$} & \multicolumn{4}{|c|}{ Board related tactics and outcomes } & \multicolumn{4}{|c|}{ Other outcomes } \\
\hline & $\begin{array}{c}\text { Seek } \\
\text { board } \\
\text { rep. }\end{array}$ & $\begin{array}{c}\text { Proxy } \\
\text { fight }\end{array}$ & $\begin{array}{l}\text { Seats } \\
\text { sought }\end{array}$ & $\begin{array}{c}\text { Proxy } \\
\text { settlement }\end{array}$ & $\begin{array}{c}\text { Acquired } \\
\text { [by third } \\
\text { party] }\end{array}$ & $\begin{array}{c}\text { Acquired } \\
\text { [by } \\
\text { activist] }\end{array}$ & $\begin{array}{l}\text { Merger } \\
\text { blocked }\end{array}$ & $\begin{array}{c}\text { Removed } \\
\text { takeover } \\
\text { defense }\end{array}$ \\
\hline & (1) & (2) & (3) & (4) & (5) & (6) & (7) & (8) \\
\hline Passive \% & $\begin{array}{c}0.905^{* *} \\
(0.403)\end{array}$ & $\begin{array}{c}0.970 * * \\
(0.405)\end{array}$ & $\begin{array}{l}0.621 * \\
(0.322)\end{array}$ & $\begin{array}{c}1.073 * * \\
(0.478)\end{array}$ & $\begin{array}{l}0.996 * \\
(0.598)\end{array}$ & $\begin{array}{l}0.522 * \\
(0.295)\end{array}$ & $\begin{array}{c}-0.928 * * \\
(0.428)\end{array}$ & $\begin{array}{c}0.298 \\
(0.239)\end{array}$ \\
\hline Polynomial order, $N$ & 2 & 2 & 2 & 2 & 2 & 2 & 2 & 2 \\
\hline Banding controls & yes & yes & yes & yes & yes & yes & yes & yes \\
\hline Float control & yes & yes & yes & yes & yes & yes & yes & yes \\
\hline Year fixed effects & yes & yes & yes & yes & yes & yes & yes & yes \\
\hline Observations & 466 & 466 & 466 & 466 & 466 & 466 & 466 & 466 \\
\hline
\end{tabular}




\section{Appendix Table 5}

\section{Robustness of findings to excluding activist campaigns that only include a 13D filing}

This table reports estimates of the second-stage regression of our instrumental variable estimation to identify the effect of institutional ownership by passive investors on our activism outcome variables when we exclude activist campaigns that only include a 13D filing. The estimation and outcomes are the same as in Tables 5-9. We instrument Passive\% using $R 2000_{i t}$, an indicator equal to one if firm $i$ is part of the Russell 2000 index in year $t$. The model is estimated using activism campaigns that target firms in the selected sample over the 2008-2014, excluding those with only a 13D filing, and includes a second-order polynomial control for $\operatorname{Ln}($ Mktcap). Standard errors, $\varepsilon$, are clustered at the firm level and reported in parentheses. * and ** indicate significance at the $10 \%$ and $5 \%$ levels, respectively.

\begin{tabular}{|c|c|c|c|c|c|c|c|c|}
\hline \multirow{3}{*}{ Dep. variable $=$} & \multicolumn{4}{|c|}{ Board related tactics and outcomes } & \multicolumn{4}{|c|}{ Other outcomes } \\
\hline & $\begin{array}{c}\text { Seek } \\
\text { board } \\
\text { rep. }\end{array}$ & $\begin{array}{l}\text { Proxy } \\
\text { fight }\end{array}$ & $\begin{array}{c}\text { Seats } \\
\text { sought }\end{array}$ & $\begin{array}{c}\text { Proxy } \\
\text { settlement }\end{array}$ & $\begin{array}{c}\text { Acquired } \\
\text { [by third } \\
\text { party] }\end{array}$ & $\begin{array}{c}\text { Acquired } \\
\text { [by } \\
\text { activist] }\end{array}$ & $\begin{array}{l}\text { Merger } \\
\text { blocked }\end{array}$ & $\begin{array}{c}\text { Removed } \\
\text { takeover } \\
\text { defense }\end{array}$ \\
\hline & $(1)$ & $(2)$ & (3) & $(4)$ & $(5)$ & $(6)$ & $(7)$ & $(8)$ \\
\hline Passive \% & $\begin{array}{c}1.179 * * \\
(0.495)\end{array}$ & $\begin{array}{c}1.152 * * \\
(0.478)\end{array}$ & $\begin{array}{c}0.756^{* *} \\
(0.371)\end{array}$ & $\begin{array}{c}1.209 * * \\
(0.559)\end{array}$ & $\begin{array}{c}1.091 \\
(0.680)\end{array}$ & $\begin{array}{l}0.663^{*} \\
(0.387)\end{array}$ & $\begin{array}{c}-1.333^{* *} \\
(0.656)\end{array}$ & $\begin{array}{c}0.488 \\
(0.310)\end{array}$ \\
\hline Polynomial order, $N$ & 2 & 2 & 2 & 2 & 2 & 2 & 2 & 2 \\
\hline Banding controls & yes & yes & yes & yes & yes & yes & yes & yes \\
\hline Float control & yes & yes & yes & yes & yes & yes & yes & yes \\
\hline Year fixed effects & yes & yes & yes & yes & yes & yes & yes & yes \\
\hline Observations & 399 & 399 & 399 & 399 & 399 & 399 & 399 & 399 \\
\hline
\end{tabular}




\section{Appendix Table 6}

\section{Robustness of findings to using $13 F$ data and quasi-index ownership}

This table reports estimates of the second-stage regression of our instrumental variable estimation to identify the effect of ownership by institutions classified as "quasi-indexers" by Bushee (2001) on our activism outcome variables. The estimation and outcomes are the same as in Tables 5-9. We instrument Quasi-index\% using $R 2000_{i t}$, an indicator equal to one if firm $i$ is part of the Russell 2000 index in year $t$. The model is estimated using activism campaigns that target firms in the selected sample over the 2008-2014 and includes a secondorder polynomial control for $\operatorname{Ln}($ Mktcap). Standard errors, $\varepsilon$, are clustered at the firm level and reported in parentheses. * indicates significance at the $10 \%$ level.

\begin{tabular}{|c|c|c|c|c|c|c|c|c|}
\hline \multirow{3}{*}{ Dep. variable $=$} & \multicolumn{4}{|c|}{ Board related tactics and outcomes } & \multicolumn{4}{|c|}{ Other outcomes } \\
\hline & $\begin{array}{c}\text { Seek } \\
\text { board } \\
\text { rep. }\end{array}$ & $\begin{array}{c}\text { Proxy } \\
\text { fight }\end{array}$ & $\begin{array}{l}\text { Seats } \\
\text { sought }\end{array}$ & $\begin{array}{c}\text { Proxy } \\
\text { settlement }\end{array}$ & $\begin{array}{c}\text { Acquired } \\
\text { [by third } \\
\text { party] }\end{array}$ & $\begin{array}{c}\text { Acquired } \\
\text { [by } \\
\text { activist] }\end{array}$ & $\begin{array}{l}\text { Merger } \\
\text { blocked }\end{array}$ & $\begin{array}{c}\text { Removed } \\
\text { takeover } \\
\text { defense }\end{array}$ \\
\hline & $(1)$ & $(2)$ & $(3)$ & $(4)$ & $(5)$ & $(6)$ & $(7)$ & $(8)$ \\
\hline Quasi-index \% & $\begin{array}{l}1.174 * \\
(0.628)\end{array}$ & $\begin{array}{l}1.188^{*} \\
(0.610)\end{array}$ & $\begin{array}{l}0.768^{*} \\
(0.445)\end{array}$ & $\begin{array}{l}1.243^{*} \\
(0.657)\end{array}$ & $\begin{array}{l}1.149 \\
(0.722)\end{array}$ & $\begin{array}{l}0.709^{*} \\
(0.402)\end{array}$ & $\begin{array}{c}-1.429 * \\
(0.848)\end{array}$ & $\begin{array}{c}0.487 \\
(0.328)\end{array}$ \\
\hline Polynomial order, $N$ & 2 & 2 & 2 & 2 & 2 & 2 & 2 & 2 \\
\hline Banding controls & yes & yes & yes & yes & yes & yes & yes & yes \\
\hline Float control & yes & yes & yes & yes & yes & yes & yes & yes \\
\hline Year fixed effects & yes & yes & yes & yes & yes & yes & yes & yes \\
\hline Observations & 466 & 466 & 466 & 466 & 466 & 466 & 466 & 466 \\
\hline
\end{tabular}

